\title{
Towards Medicines Reuse: A Narrative Review of the Different Therapeutic Classes and Dosage Forms of Medication Waste in Different Countries
}

\author{
Hamza Alhamad ${ }^{1,2, * \mathbb{C}}$, Nilesh Patel ${ }^{1}\left(\mathbb{D}\right.$ and Parastou Donyai ${ }^{1} \mathbb{D}$ \\ 1 Department of Pharmacy, University of Reading, Reading RG6 6AP, UK; nilesh.patel@reading.ac.uk (N.P.); \\ p.donyai@reading.ac.uk (P.D.) \\ 2 Department of Pharmacy, Zarqa University, 132222 Zarqa, Jordan \\ * Correspondence: halhamad@zu.edu.jo
}

Received: 2 September 2020; Accepted: 27 November 2020; Published: 1 December 2020

\begin{abstract}
Background: Medicines reuse, the idea of re-dispensing returned medicines to others following quality control, is yet to be implemented in the UK. This practice is potentially a sustainable way of dealing with returned medicines, which are otherwise classed as medication waste and destroyed. To inch towards medicines reuse, it is important to know more about the different therapeutic classes and dosage forms that make up medication waste. For example, it is helpful to know if medicines being returned are mostly solid-dosage forms and thus have the potential to be reused or are from therapeutic classes that would make medicines reuse cost-effective. Little is known about the therapeutic classes and the dosage forms of wasted medicines. This study aimed to narratively review and report findings from the international literature on the different therapeutic classes and the dosage forms of medicines that are returned by patients to community pharmacies, hospitals, general practitioners' clinics, or collected through waste campaigns. Studies based on surveys without physically returning medicines were also included where relevant. Methods: A comprehensive electronic search of databases, including PubMed and Google Scholar, was carried out over one month in 2017 and updated by 5 November 2020, using a combination of carefully created keywords. Results: Forty-five studies published in English between 2002 and 2020, comprising data from 26 countries were included and reviewed. Oral solid dosage forms (mostly tablets) were the commonly reported dosage form of all wasted medicines in 14 studies out of the 22 studies $(64 \%)$ that described the dosage form, with percentages ranging from $40.6 \%$ to $95.6 \%$ of all wasted medicines. Although there was variability among the levels of medication waste reported in different countries, findings from the UK and Ethiopia were relatively consistent; in these, medicines for the cardiovascular system and anti-infective medicines, respectively, were the most common therapeutic classes for medication waste. Conclusion: This narrative review provides insights about the different therapeutic classes and dosage forms of medication waste either returned by patients, collected through waste campaigns, or indicated in survey responses. The findings could help policy makers understand the potential implications of treating most unused medicines as medication waste and whether therefore pursuing a medicines reuse scheme could be environmentally or financially logical. The quality and the safety of these returned medicines using criteria related to the storage conditions (such as heat and humidity), physical shape (such as being sealed, unopened, unused, and in blister packaging), and tampering are other important considerations for a medicines reuse scheme.
\end{abstract}

Keywords: medicines reuse; medication waste; therapeutic class; dosage form; sustainability; waste management 


\section{Introduction}

Waste can be referred to as any substance or object the holder discards, intends to discard, or is required to discard [1]. The World Health Organisation (WHO) defines pharmaceutical or medication waste as "expired, unused, spilt, and contaminated pharmaceutical products, drugs, vaccines and sera" [2]. Medication waste is a growing problem in the UK and different parts of the world in terms of its negative impact on governmental expenditures, the environment, and human health [3-7]. Waste associated with prescribed medicines cost the National Health Service (NHS) in England an estimated $£ 300$ million a year in $2009, £ 110$ million of which related to medicines returned to community pharmacies for disposal [6]. However, the financial cost is only one part of the medication waste burden. The negative impact on the environment is also significant with one reason for finding pharmaceuticals in the water environment [7] being the improper disposal of medication waste $[8,9]$. The presence of medication waste in the environment can modify the physiological function of living creatures and has been linked to the possible emergence of antibiotic-resistant bacteria such as vancomycin-resistant enterococci and beta-lactam-hydrolysing Enterobacteriaceae [10], as well as the feminising effects of endocrine deactivating compounds such as ethinyl estradiol [11]. The risk to human health is not limited to pollution and contamination of the drinking water, as there is also a risk when others in the home consume unused medicines that have been stockpiled but ought to have been dealt with safely. For example, patients might self-medicate for a new illness with medication previously prescribed for a different illness, causing harm through misdiagnosis or mistreatment [12]; there might be accidental poisoning if children use stockpiled medicines; and medicine abuse might occur where the medicines are controlled or have addictive properties [13].

The causes of medication waste are divided into preventable (e.g., patient stockpiles medicines, overprescribing, or repeat dispensing of unwanted medicines), non-preventable (e.g., death of a patient, or a change in the prescription meaning the previous medicines are no longer required) and non-adherence behaviours $[1,6,14]$. Therefore, prevention is one way to reduce medication waste. Preventing waste is in fact the top option according to the Waste Hierarchy, which is a grading framework that ranks waste management options according to what is best for the environment, with "prepare for reuse", "recycle", "other recovery", and "disposal" following "prevention" in decreasing preference order [15]. Many interventions have been attempted to prevent medication waste, but these have not always been effective, as the most common causes of medication waste are actually non-preventable [14]. Medicines reuse-the idea of re-dispensing returned medicines to others following quality control-is an underexplored concept in the UK but could help reduce medication waste regardless of the cause. What is more, qualitative studies have previously analysed intentions and actions towards the reusing of medication waste, reporting a possible future for the idea [16-19]. Numerous factors influence the practicalities of such an idea, including the prior storage conditions, as well as the therapeutic classes and the dosages forms of medicines considered to be waste but which might then be reused. Knowing information about the different therapeutic classes and dosage forms of medication waste creates some understanding of which medicines might potentially be up for reuse. For example, it is helpful to know if medicines being returned are mostly solid-dosage forms (thus having the potential to be reused), or liquids, injectables, etc., and whether these medicines are over the counter (cheaper/not critical to NHS costs) or other therapeutic classes that could be more relevant in terms of environmental sustainability or cost-effectiveness.

Despite a thorough literature review on the causes of medication waste [6,14,20-23], the financial $[4,6,20,24-28]$ and environmental impact of medication waste $[7,10,11]$, medicine disposal practices $[8,9,22,24,28-34]$, and management strategies of medication waste $[6,14]$, only some studies have reported the type and therapeutic classes and dosage forms of unused or returned medication waste, and none have brought the information together in a focused review $[6,23,28]$. This study aimed to narratively review and report findings from the literature about the different therapeutic classes and the dosage forms of medication waste that are returned by patients to community pharmacies, hospitals, general practitioners' clinics, or collected through waste campaigns in different countries 
around the world. Results from studies based on surveys (without the physical return of medicines) were also included to take account of relevant data collected via this alternative method.

\section{Materials and Methods}

A search of electronic databases was carried out over one month in 2017 and updated in 2020 ending on 5 November 2020 to identify reports and studies published in English detailing therapeutic classes and dosage forms of medication waste. Electronic databases searched comprised PubMed/Medline, Cochrane library, Grey literature (open grey and British library), National Audit Office (NAO), and National Institute for Health and Care Excellence (NICE) evidence. The bibliographies of retrieved references were also searched.

The search activity used combinations of a list of terms that included the following: types of unused medicines OR classes of unused medicines OR dosage forms of unused medicines OR types of medicine waste OR classes of medicine waste OR dosage forms of medicine waste OR types of unused drugs OR classes of unused drugs OR dosage forms of unused drugs OR types of drug waste OR classes of drug waste OR dosage forms of drug waste.

The inclusion criteria aimed to select studies published in English that reported the therapeutic classes and dosage forms of returned medication waste, either dispensed following a prescription or purchased over the counter (OTC), or a medicine sample that had expired (or had no clear expiry date) or was never fully consumed (or not used at all). Studies describing medical waste, medical device waste, and/or clinical tissue waste were excluded.

Study selection was completed by two researchers (H.A. and N.P.) using a Preferred Reporting Items for Systematic Reviews and Meta-Analyses (PRISMA) flow of identification, screening, eligibility, and inclusion [35] (Figure 1). At first, 3390 candidate studies were identified; then, 18 duplicates were removed. All study titles and abstracts of the remaining 3372 studies were screened, with 3311 studies removed, resulting in 61 potentially eligible studies. After a thorough full-text review of the 61 studies to assess for eligibility, 45 studies published between 2002 and 2020 were included in this narrative review. Data obtained from the retrieved studies described demographic information of the participants, the types and dosage forms of medication waste, study settings and sample size, and the time/duration of the collection of the returned medicines (varying from 4 weeks up to 12 months).

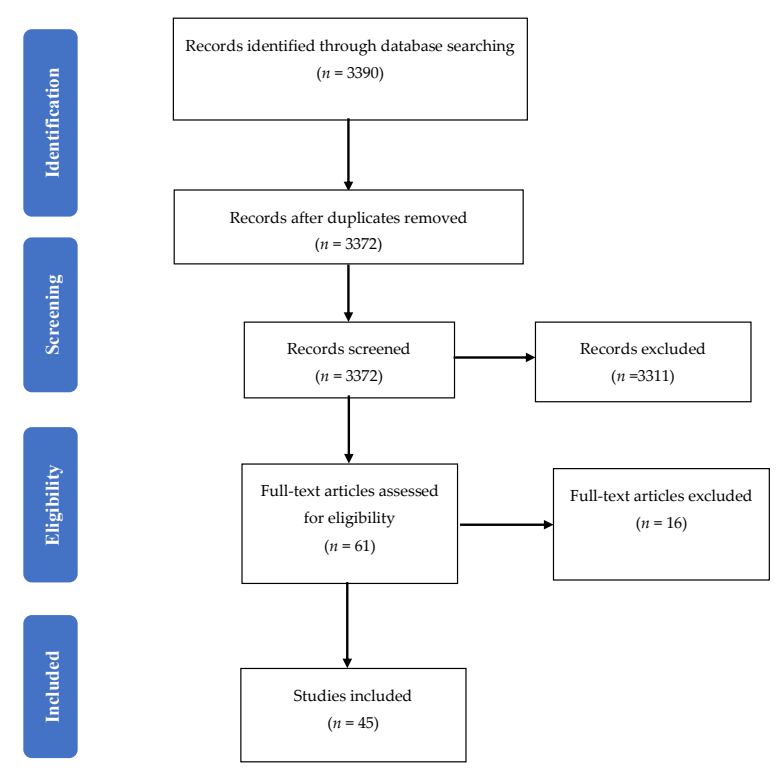

Figure 1. Literature search scope using the PRISMA flow chart adapted from the PRISMA Group, 2009 [35]. 


\section{Results}

The search yielded 3390 candidate studies. A total of forty-five studies published between 2002 and 2020 and comprising data from 26 different countries from around the world (Australia, Austria, Egypt, Ghana, India, Jordan, Kuwait, Malaysia, Mexico, New Zealand, Oman, Qatar, Saudi Arabia, Spain, Taiwan, Tanzania, Thailand, United Arab Emirates, United Kingdom, United States of America, China, Malta, Indonesia, Iraq, Nigeria, and Ethiopia) were included and reviewed. In some of these studies, medication waste was returned by patients to community pharmacies, general practitioners' clinics, hospitals or sometimes collected via medicine take-back and medicine waste campaigns. However, twenty nine (the majority) studies used a survey to collect information about the therapeutic classes and dosage forms of medication waste by asking participants for information without physically collecting the waste: six studies from Ethiopia [36-41], three from India [42-44], two from Malaysia [24,45], two from the USA [34,46], two from Jordan [47,48], two from Egypt [26,49], two from Thailand [20,50], one from Qatar [51], one from China [52], one from Iraq [53], one from Indonesia [54], one from Nigeria [55], one from Spain [56], one from Saudi Arabia [27], one from Tanzania [57], one from Malta [58], and one from Ghana [59]. The methodologies used and the targeted populations are summarised in Appendix A Table A1.

\subsection{Studies' Samples}

The studies' samples were reported in different ways. Most studies reported sample size as the number of medication waste items returned or collected. Other studies reported the sample as per weight $(\mathrm{kg})$, per bag, packs, or containers of the collected returned medication waste. The sample for survey-based studies was reported as the number of completed questionnaires collected or the number of participants surveyed. For more details about the sample of the studies included, please refer to Appendix A Table A1.

\subsection{Demographics of the Participants}

Gender was not reported in the majority of the studies (Appendix A Table A1). Fifteen studies (36\% of the retrieved studies) described the gender of the participants, and it was not apparent that there is a gender difference associated with the presence/reporting of medication waste. For example, more women took part in seven of the studies $[20,38,45,52,54,56,57]$ and more men took part in eight of the studies [36,37,39,40,42,49,55,59]. In the study from Egypt [49], the number of people who returned their medication waste happened to be more male than female and one study from Malaysia [24] recruited female students only.

Age of participants was described in 23 studies out of 45 studies (51\%) (Appendix A Table A1). Participants' age profile varied in these studies and was up to 81 years. Twelve studies of the 23 studies $(25 \%)$ found an apparent relationship between the mean number of returned medicinal items per patient and their age. Here, the majority of medication waste was reported to be from participants with the age ranges of $60-80$ years [21,31,32,49,57]. Two studies [43,59] had more data relating to participants in the age range 20-40, but this was an artefact of the study designs, focussing on students who are likely to be in that younger age range. It is not possible to conclude that the age range of 60-80 years was associated with more medication waste as, additionally, age data was absent from half of the studies $(49 \%)$.

\subsection{Dosage Forms of Returned Medication Waste}

Dosage forms were investigated in 22 out of the 45 studies $(49 \%)$ on medication waste (Appendix A Table A2). Dosage forms included a range of oral solid dosage forms (tablets, capsules, granules, powders, and lozenges), liquids (syrups, injections, eye drops, suspensions, emulsions, and lotions), semisolids (ointments, creams, gel, paste and suppositories), and other items such as inhalers, sprays, patches, strips, and chewing gum. Oral dosage forms were the most commonly 
reported formulation in fourteen studies out of $22(64 \%)$ with percentages ranging from $40.6 \%$ to $95.6 \%$ of all medication waste. Moreover, tablets were reported to be the most common of the oral dosage forms.

One study from Oman (60) reported that during handling of the dosage forms, most of them appeared in a suitable condition for reuse and were still in their original container. However, some had changed in colour, consistency, and odour and therefore were deemed not to be suitable for reuse. Results from a UK study [36] were consistent with the Oman study [60] in which many of the returned medication waste items were reported to be in a condition suitable for reuse as assessed by a pharmacist. These were the only two studies that directly commented on whether the medication waste returned was potentially suitable for reuse.

\subsection{Therapeutic Category of the Returned Medication Waste}

Except for two studies $[31,57]$ in which only prescribed medicines were included in the authors' analysis, the majority of the studies include both prescribed and OTC medicines. Moreover, only three studies $[25,26,61]$ included medicinal samples in addition to prescribed and OTC medicines.

The majority of the studies ( 42 out of the total 45 ) reported the therapeutic category of the medication waste, and these were included in the current analysis (Appendix A Table A2). The remaining three studies reported the medication waste individually by generic or brand name and were therefore excluded from the current analysis.

The therapeutic categorisation systems used for reporting the findings were not the same in all studies. Seven studies used the British National Formulary (BNF) categories [6,26,49,60,62-64]. Seven studies used the Anatomical Therapeutic Chemical Coding (ATC) of the WHO $[33,36,48,56,58,65,66]$. Other ways of therapeutic categorisation included national codings such as the Saudi National Formulary (SNF) [27], Chinese Pharmacopoeia [52], and the Monthly Index of Medical Specialities online (MIMS) [20]. The remaining studies used disease and class of medicine classification such as diabetes/anti-diabetic. A breadth of therapeutic categories reported included cardiovascular system (CVS), central nervous system (CNS), alimentary tract/gastrointestinal tract (GIT), respiratory system, musculoskeletal system and joint disease, analgesics and antipyretics, non-steroidal anti-inflammatory drugs (NSAIDs), endocrine system, malignant disease and anticancer medicines, nutrition and blood, vitamins and minerals, gynaecology and medicines for urinary tract infection (UTI), antibiotics, medicines for ear, nose, and oropharynx, and skin medicines.

Eight studies out of the $42(19 \%)$ reported that CVS medicines were the most common therapeutic category of medication waste $[6,32,49,60,62-64,66]$. Similarly, eight studies out of $42(19 \%)$ reported that anti-infective medicines were the most common therapeutic category of medication waste $[26,36-41,57]$. CNS medicines were reported in five studies out of the $42(12 \%)$ as the most common therapeutic category of medication waste $[21,31,47,51,65]$.

The different therapeutic categorisation systems used in reporting medication waste (sometimes in studies completed in the same country) make the interpretation of results difficult. For example, two studies, one from India [42], and one from the USA [25], combined analgesics with nonsteroidal anti-inflammatory drugs (NSAIDs) into one therapeutic category, while five studies from India [43], the USA [34,46], Mexico [61], and Thailand [50] described analgesics and antipyretics as one category and musculoskeletal and joint disease medicines as another category. In addition, the number of studies that investigated medication waste by therapeutic categorisation was more likely to be from a small number of countries. For example, seventeen studies out of forty-two (40\%) were from four countries: the UK $[6,13,62,64]$, Ethiopia [36-41], New Zealand [21,31,65,67], and the USA [25,34,46]. This makes reporting of the results by the number of studies less representative of the international literature.

Therefore, in order to synthesise the results for this narrative review, all the different therapeutic categories were re-classified according to the BNF categorisation system and then represented by country (Figure 2). For example, NSAIDs were re-classified under musculoskeletal system medicines (BNF Chapter 10), analgesic and antipyretics were re-classified under CNS medicines (BNF Chapter 
4), and alimentary tract system medicines were re-classified under gastrointestinal system medicines (BNF Chapter 1). In addition, in countries where more than one report was found, such as the Ethiopia, UK, New Zealand, Jordan, and Egypt, the sum of all returns of medication waste was calculated and reported by country.

Figure 2 shows the results of the common therapeutic categories of medication waste reported by country and after re-classification according to the BNF categorisation system. In the UK, CVS medicines were the most common therapeutic class of medication waste, with CNS medicines being the second most common therapeutic class. Other therapeutic categories of medication waste, such as gastrointestinal and respiratory medicines, were also reported but less commonly in the UK. Similar results to the UK were reported from countries such as Australia, Austria, Mexico, and Oman where CVS medicines were the most common therapeutic class of medication waste. Moreover, in Mexico, Australia, and Austria, musculoskeletal system medicines were also common and the second most reported category.

In New Zealand, CNS medicines were the most common therapeutic class of medication waste. Other therapeutic categories such as gastrointestinal, cardiovascular, and musculoskeletal system medicines (with diclofenac sodium and ibuprofen reported to be commonly returned as waste) were also reported in studies from New Zealand but less than CNS medicines. In Jordan and Qatar, results were similar to New Zealand, where CNS medicines were the most common therapeutic class of medication waste. In Jordan and Qatar, paracetamol was the most common individual tablet considered as waste. In addition, in Jordan, gastrointestinal medicines were reported as the second most common therapeutic class of medication waste followed by anti-infective medicines. In Qatar, anti-infective medicines were reported as the second most common therapeutic class of medication waste. Other therapeutic categories of medication waste such as musculoskeletal system medicines were reported in Jordan and Qatar but less commonly.

In Spain, both the gastrointestinal system and CNS medicines were the most common therapeutic classes of medication waste. In Taiwan, gastrointestinal system and CVS were the most common therapeutic classes of medication waste. While in Saudi Arabia, both the respiratory system and CNS medicines were the most common therapeutic classes of medication waste.

In Ethiopia, Egypt, and Tanzania, anti-infective medicines were the most common therapeutic class of medication waste. The CNS medicines (in Ethiopia), and CVS medicines (in Egypt and Tanzania) were reported as the second most common therapeutic class of medication waste. Other therapeutic categories of medication waste such as musculoskeletal and gastrointestinal system medicines were reported in Ethiopia, Egypt, and Tanzania, but less so.

Studies from the USA, Thailand, India, and Indonesia showed that musculoskeletal system medicines were the most common therapeutic class of medication waste in these countries. Finally, in Malaysia, vitamins and minerals were the most common therapeutic category of medication waste. 


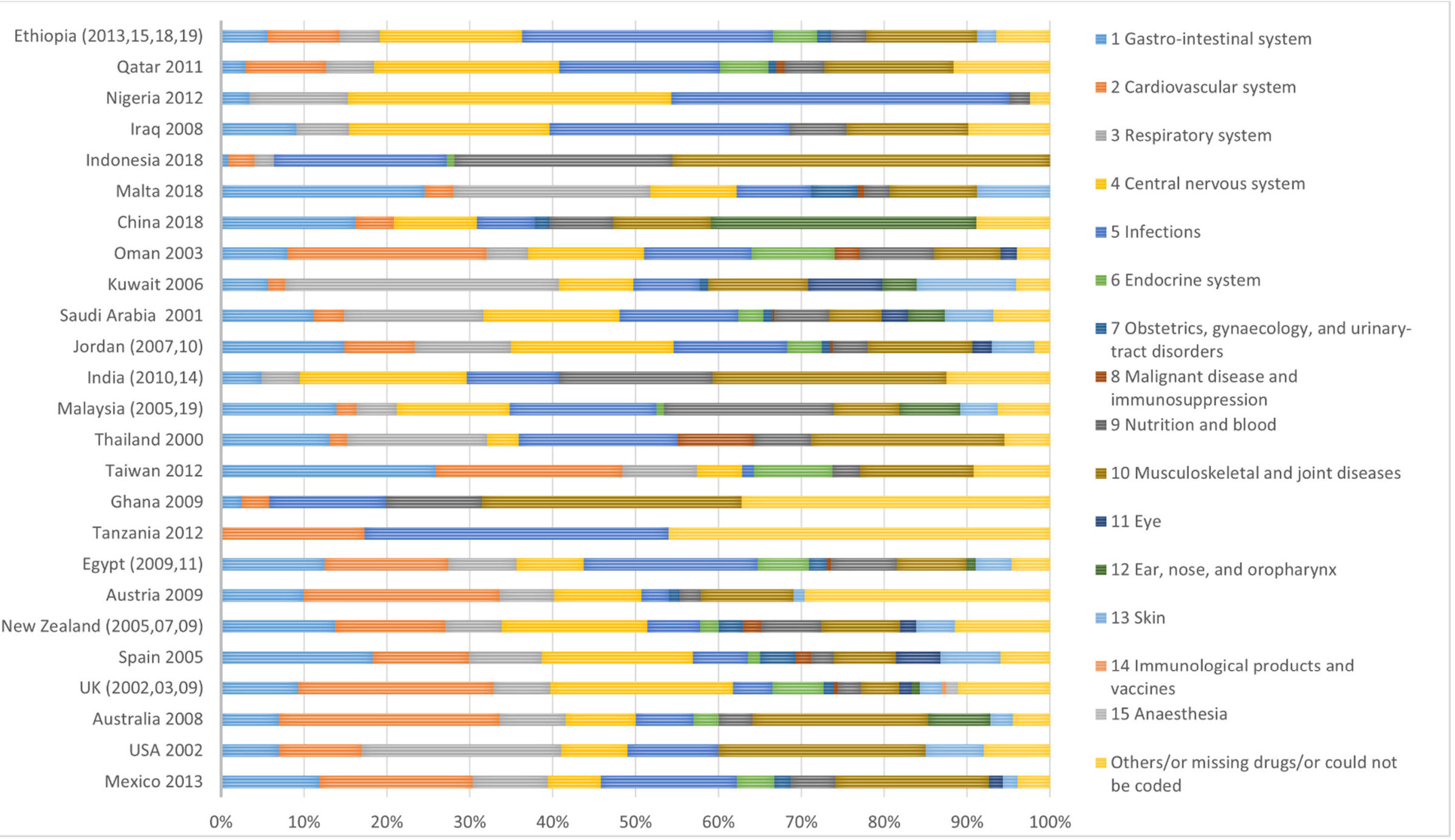

Figure 2. The common therapeutic categories of medicine waste reported from different countries in the world by year of data collection, re-classified according to the British National Formulary (BNF) categorisation system. 


\section{Discussion}

Despite the extensive literature on medication waste, no literature review to date had explicitly focused on the therapeutic classes and the dosage forms of medication waste items. This narrative review addresses that gap. The principal finding is that CVS (certainly in the UK) and anti-infective (certainly in some African countries) medicines are reported as some of the most commonly returned/accumulated medication waste category. Arguably, knowing the therapeutic category of medication waste is as crucial as the quantity of the returned medication waste in terms of environmental and financial potential for medicines reuse. This is because medicines in certain therapeutic categories cost more. For example, one UK study [63] reported the volume of waste relating to respiratory system medicines to be about half $(8 \%)$ that reported for CNS medicines (19\%), but the cost of the medicines in the respiratory group was about the same as those in the CNS category. Thus, knowing the therapeutic categorization of medication waste makes it easier to judge where medicines reuse might be financially logical. It is of course essential to quality assure the safety of any returned medicines using criteria related to the storage conditions (such as heat and humidity), physical shape (such as being sealed, unopened, unused, and within blister packs), and tampering. Two studies conducted in Oman [60] and the UK [63] directly commented on whether the medication waste returned was potentially suitable for reuse. These studies reported that during handling of the dosage forms, most of the returned medicines appeared in a suitable condition for reuse and were still in their original container, with only a few having changed in colour, consistency, and odour; thus, these were deemed unsuitable for reuse. Findings of these studies are also important considering that unused medicines from the so-called developed world are sometimes sent for reuse to so-called developing countries.

In the UK, CVS medicines were the most common therapeutic class of medication waste. A possible explanation is that CVS medicines are one of the commonly prescribed medicines in the UK, comprising approximately $20 \%$ of all the medicines prescribed because of the prevalence of cardiovascular disease. Moreover, CVS medicines are one of the commonly amended classes of medicines because of frequent changes in doses and drugs necessitated by guidelines [62]. In Ethiopia, Egypt, and Tanzania, anti-infective medicines were the most common therapeutic class of medication waste. This is possibly because antibiotics have been available without a prescription in these countries, where also it is common for people not to complete their course of antibiotic treatment when their symptoms resolve. In New Zealand and Jordan, CNS medicines were the most common therapeutic class of medication waste with paracetamol as the most common individual tablet returned as waste. The potential explanation here is that analgesics (with paracetamol reported to be the most common) are frequently used for the self-medication of headaches, which is a commonplace discomfort. Similarly, in the USA, Thailand, and India, the musculoskeletal system medicines were the most common therapeutic class of medication waste with NSAIDs being the most common group reported in these countries, again reflecting their common usage. In the study from Malaysia, vitamins and minerals were reported as the most common therapeutic category of medication waste, but this is likely an artefact of the methods, which only sampled female students.

This narrative review synthesised information about the most commonly found medication waste products from different countries around the world. However, the results should be interpreted carefully. First, the findings apply to medication waste that was returned by patients only or reported in surveys and does not take into account the substantial amount of medication waste likely to be disposed of into household garbage or via the sink or simply kept stockpiled unreported at home [65]. Second, the small sample size and the small number of returns of medication waste in the majority of the studies made these studies less likely to be representative of a global picture. Third, the CNS classification of paracetamol as the most commonly reported item as waste raised the percentages of waste from the CNS therapeutic class compared to other therapeutic classes such as musculoskeletal, alimentary tract, and respiratory systems. Paracetamol is considered cheap, and one may argue that it is not worthwhile to set up a medicines reuse system if this is the largest category of returned medicines in any one country. Fourth, the quality of the studies included in this narrative review was not checked because 
of the disparity of methods and a lack of specific criteria, which could affect the results reported (as none of the papers found were excluded) and could be seen as another limitation of this study. Finally, the results of this narrative review cannot be generalised. For example, results from Ethiopia, Egypt, and Tanzania of having antibiotics as the most common therapeutic category of medication waste cannot be generalised (although reported to be the commonest along with CVS medicines) to other countries where antibiotics are only available with a prescription such as in the UK or the USA. In addition, results from the two Malaysian studies, which reported that vitamins and minerals were the most common therapeutic category of medication waste, is impossible to generalise to the larger population, as one study was only completed with female Malaysian students (no males). The other Malaysian study was also completed by more females than males.

This narrative review has other limitations that should also be acknowledged. First, it included results from reports, theses, audits, and the grey literature, but there is always a risk that some studies were not included as a result of not performing a thorough enough systematic search. Second, the search strategy was restricted to studies that were published in the English language only and so could have missed other valuable research. Third, the reasons behind the accumulation of the returned medication waste from each therapeutic category were not clearly evidenced in all the studies. Some studies provided possible explanations that may apply only to the country from which data were obtained, and therefore, it may not be appropriate to generalise these explanations. Finally, information about what motivates people to return their medication waste and if they returned a certain type of medication waste over others were not investigated and remain unknown.

This review is the first to provide narrative information about the different therapeutic categories and dosages forms of returned medication waste from different countries around the world. Pooling information about the different therapeutic classes and dosage forms of medication waste can help increase knowledge about medicines that are returned unused and or otherwise classed as wasted medicines, so that extrapolations can be made about the costs of waste and whether it is worthwhile to reuse these medicines. For example, paracetamol is considered cheap, and one may argue that it is not worthwhile to set up a medicines reuse system if this is the largest category of returned medicines in any one country. In addition, oral solid dosage forms are more likely to be suitable candidates for reuse compared to other dosage forms such as liquids or injectables; therefore, it is useful to know where this is the most commonly returned formulation. However, a pharmacist's hand inspection of such medicines would not be sufficient to address concerns about the quality and the safety of returned medicines. For example, there would also need to be additional checks in place for storage conditions (e.g., under excessive heat and humidity), and physical characteristics (such as being sealed, unopened, unused, and being in a blister) which could indicate (non-)tampering, degradation or contamination, in addition to the visual indicators. These concerns would need to be addressed before medicines reuse becomes a reality $[23,68]$, and one way to do this would be through the application of technology $[69,70]$.

This narrative review identified a large number of studies from the literature that investigated the different therapeutic classes and the dosage forms of medication waste returned by patients to healthcare settings, and through waste campaigns, as well as information obtained from survey responses. Although there was variability among the levels of medication waste reported in different countries, findings from some countries such as the UK and Ethiopia were relatively consistent and appeared to reflect the local usage of these medicines. This suggests that medication waste categories might be proportional to the prevalence of medicines in each specific country, which remains to be tested in future studies. Future studies that focus on assessing the quality and the safety of retuned medicines, and exploring public and healthcare providers' perception about medicines reuse should also be performed before medicines reuse becomes a reality. For example, contained sites such as long-term care facilities or hospice care settings where the medications are presumably stored correctly might be more capable of reusing medicines and could be a realistic site for trialling medicines reuse in the future. 


\section{Conclusions}

Findings from this narrative review provide insight about the different dosages forms and the therapeutic classes of medication waste, which can be used to support future medicines reuse-related research and explorations. It appears that the therapeutic categories of medication waste are reflecting prevalence of usage, inviting policy makers in each country to reflect on whether medicines reuse could be cost-effective in their own settings. Any medicines reuse scheme would still need to consider quality and safety checking of returned medicines over and above the pharmacists' visual checks.

Author Contributions: P.D.: Conceptualisation, Supervision, Project administration, Validation, Visualisation, Writing_-Reviewing and Editing, Resources. N.P.: Conceptualisation, Supervision, Project administration, Validation, Visualisation, Writing-Reviewing and Editing, Resources. H.A.: Conceptualisation, Methodology, Investigation, Data Curation, Formal analysis, Validation, Visualisation, Writing-Original draft preparation. All authors have read and agreed to the published version of the manuscript.

Funding: This research was part of a PhD project sponsored and funded by Al-Zarqa University (under the regulation of the Jordanian Ministry of Higher Education).

Acknowledgments: We thank Zarqa University for the funding of the PhD project.

Conflicts of Interest: The authors declare that they have no conflict of interest to disclose. 


\section{Appendix A}

Table A1. Summary of the research instrument, sample, and demographics of the included studies.

\begin{tabular}{|c|c|c|c|c|c|c|}
\hline Year of Study & Author(s) & Country/Settings & Research Instrument & $\begin{array}{c}\text { Wasted Medicines } \\
\text { Information (e.g., Take Back } \\
\text { Campaigns vs. Survey) }\end{array}$ & Sample & Demographics \\
\hline 2015 & Gracia-Vásquez et al. [61] & $\begin{array}{l}\text { Mexico; nine cities } \\
\text { of Monterrey }\end{array}$ & $\begin{array}{l}\text { Unused/expired medications were collected } \\
\text { from households in a special container } \\
\text { placed in a visible and accessible location in } \\
85 \text { collection centres in community } \\
\text { pharmacies located in nine cities in the } \\
\text { Monterrey metropolitan area over } 12 \\
\text { months from March } 2012 \text { to February } 2013\end{array}$ & Take back program. & $\begin{array}{l}\text { Random sample of } 22,140 \\
\text { items, } 30 \% \text { of total drugs } \\
\text { collected over } 12 \text { months), } \\
\text { as } 70 \% \text { were unable to } \\
\text { be classified. }\end{array}$ & Not studied. \\
\hline 2008 & Braund et al. [21] & New Zealand & $\begin{array}{l}\text { Over a five-week period medications were } \\
\text { returned to two collection point pharmacies } \\
\text { and questionnaires were completed by } \\
\text { returners. }\end{array}$ & $\begin{array}{l}\text { Take back program. } \\
\text { In addition, a questionnaire } \\
\text { was completed to determine } \\
\text { the reasons that the } \\
\text { medications were not used. }\end{array}$ & $\begin{array}{l}163 \text { returns, comprising of } \\
1399 \text { items, with only } 126 \\
\text { returned questionnaires. }\end{array}$ & $\begin{array}{l}\text { The majority of those } \\
\text { returning medications fall } \\
\text { within the age range of } \\
61-80 \text { years. }\end{array}$ \\
\hline 2007 & Braund et al. [67] & $\begin{array}{l}\text { New Zealand; } \\
\text { Otago Pharmacies }\end{array}$ & $\begin{array}{l}\text { Medications returned unsolicited to Otago } \\
\text { pharmacies over a 9-month period, from } 1 \\
\text { April to } 31 \text { December } 2005 .\end{array}$ & Take back program. & $\begin{array}{l}\text { A random sample }(159 \mathrm{~kg}, 12 \%) \\
\text { of the } 1294 \mathrm{~kg} \text { of medications } \\
\text { returned for destruction over } \\
\text { a nine-month period from the } \\
\text { Otago region were identified. }\end{array}$ & Not studied. \\
\hline 2009 & Braund et al. [31] & $\begin{array}{l}\text { New Zealand; Hutt } \\
\text { Valley District Health } \\
\text { Board }\end{array}$ & $\begin{array}{l}\text { A Disposal of Unwanted Medication } \\
\text { Properly (DUMP) campaign was conducted } \\
\text { for } 4 \text { weeks in November } 2007 \text { in } 31 \\
\text { community pharmacies. Questionnaires } \\
\text { were completed by the returners. }\end{array}$ & $\begin{array}{l}\text { Take back program. } \\
\text { 'Disposal of Unwanted } \\
\text { Medication Properly } \\
\text { (DUMP)' campaign. }\end{array}$ & $\begin{array}{l}\text { Of the total } 1605 \text { bags returned } \\
\text { over } 4 \text { weeks for disposal, } \\
\text { only } 329 \text { bags }(20 \%), \\
\text { containing a total of } 1253 \text { items } \\
\text { were fully analysed. Only } 653 \\
\text { questionnaires were } \\
\text { completed }(41 \%) .\end{array}$ & $\begin{array}{l}\text { The age distribution of } \\
\text { the patients with unused } \\
\text { medications was } \\
<20(8 \%), 21-40(13 \%), \\
41-60(28 \%), 61-80(40 \%) \\
\text { and }>81 \text { years }(11 \%) .\end{array}$ \\
\hline 2010 & Caroline et al. [29] & $\begin{array}{l}\text { New Zealand; } \\
\text { Nelson Bays region }\end{array}$ & $\begin{array}{c}\text { A Disposal of Unwanted Medication } \\
\text { Properly (DUMP) campaign was conducted } \\
\text { for } 5 \text { weeks in November and December } \\
2009 \text { and for } 3 \text { weeks afterwards. Surveys } \\
\text { were completed in } 379 \text { bags. }\end{array}$ & $\begin{array}{l}\text { Take back program. } \\
\text { 'Disposal of Unwanted } \\
\text { Medication Properly } \\
\text { (DUMP)' campaign. }\end{array}$ & $\begin{array}{l}\text { Of the } 6500 \text { DUMP bags } \\
\text { distributed across the Nelson } \\
\text { Bays region, } 1244 \text { bags were } \\
\text { returned (response rate } 19 \%), \\
\text { with an average of } 7 \text { items per } \\
\text { bag (number of items } \\
\text { returned } 8609 \text { ). }\end{array}$ & Not studied. \\
\hline
\end{tabular}


Table A1. Cont.

\begin{tabular}{|c|c|c|c|c|c|c|}
\hline Year of Study & Author(s) & Country/Settings & Research Instrument & $\begin{array}{c}\text { Wasted Medicines } \\
\text { Information (e.g., Take Back } \\
\text { Campaigns vs. Survey) }\end{array}$ & Sample & Demographics \\
\hline 2009 & James et al. [65] & $\begin{array}{c}\text { New Zealand: } \\
\text { Taranaki region } \\
\text { (around } 37,000 \text { households) }\end{array}$ & $\begin{array}{l}\text { Unused medications returned for disposal } \\
\text { to the } 24 \text { community Pharmacies in the } \\
\text { Taranaki region ( } \approx 37,000 \text { households) of } \\
\text { New Zealand over } 6 \text { weeks. }\end{array}$ & Take back program. & $\begin{array}{l}716 \text { individuals returned } 3777 \\
\text { items of unused medications. } \\
\text { Of the } 3777 \text {, information for the } \\
\text { amount issued and returned } \\
\text { was complete for } 2704 . \\
\text { The majority }(51 \%) \text { of returns } \\
\text { contained } 75-100 \% \text { of the } \\
\text { original dispensed amount } \\
\text { of medication. }\end{array}$ & Not studied. \\
\hline 2005 & Langley et al. [62] & $\begin{array}{l}\text { United Kingdom; } \\
\text { East Birmingham }\end{array}$ & $\begin{array}{l}\text { Unused medications returned to } \\
8 \text { community pharmacies and } 5 \text { general } \\
\text { practices (G.P.) surgeries over } 4 \text { weeks each } \\
\text { (4 weeks during August } 2001,4 \text { weeks } \\
\text { during March 2002, respectively). }\end{array}$ & $\begin{array}{l}\text { No return campaign was } \\
\text { conducted and no attempt } \\
\text { was made to encourage } \\
\text { patients or carers into } \\
\text { returning medicines. } \\
\text { Medicines returned to } \\
8 \text { community pharmacies } \\
\text { and } 5 \text { general practices (G.P.) } \\
\text { surgeries over } 4 \text { weeks } \\
\text { were assessed. }\end{array}$ & $\begin{array}{l}\text { A total of } 114 \text { returns; } \\
24(21.1 \%) \text { to G.P. surgeries and } \\
90(78.9 \%) \text { to community } \\
\text { pharmacies. The total returns } \\
\text { comprised } 340 \text { items, of which } \\
42(12.4 \%) \text { were returned to } \\
\text { G.P.s and } 298(87.6 \%) \text { to } \\
\text { community pharmacies. }\end{array}$ & $\begin{array}{l}\text { Older patients ( } 60 \text { years } \\
\text { and over) returned } 61.4 \% \\
\text { of items with } 24.6 \% \text { of } \\
\text { returns coming from } \\
\text { patients aged } 30-59 \text { years } \\
\text { and } 5.3 \% \text { of returns } \\
\text { originating from patients } \\
\text { under 30. Ages were not } \\
\text { recorded for } 8.7 \% \\
\text { of returns. }\end{array}$ \\
\hline 2007 & Mackridge et al. [63] & $\begin{array}{l}\text { United Kingdom; Eastern } \\
\text { Birmingham Primary } \\
\text { Care Trust (P.C.T.) }\end{array}$ & $\begin{array}{l}\text { Unused medications returned to pharmacies } \\
\text { and G.P. surgeries were collected over } 8 \\
\text { weeks in May and June } 2003 \text { in Eastern } \\
\text { Birmingham Primary Care Trust (P.C.T.). } \\
\text { Three-quarters of the P.C.T. sites } \\
\text { participated, } 51 / 60 \text { (85\%) pharmacies and } \\
\text { 42/61 (70.5\%) G.P. surgeries. }\end{array}$ & $\begin{array}{l}\text { Unused medicines were } \\
\text { returned and data were } \\
\text { collected in Eastern } \\
\text { Birmingham Primary Care } \\
\text { Trust (PCT), a predominantly } \\
\text { urban PCT with an ethnic } \\
\text { minority population of } 20 \% .\end{array}$ & $\begin{array}{l}934 \text { return events were made } \\
\text { from } 910 \text { patients (190 GP } \\
\text { surgeries, } 744 \text { pharmacies), } \\
\text { comprising } 3765 \text { items ( } 431 \mathrm{GP} \\
\text { surgeries, } 3334 \text { pharmacies) } \\
\text { and totalling } 4934 \\
\text { individual packs. }\end{array}$ & $\begin{array}{l}\text { The mean age of } \\
63.5 \pm 0.78 \text { years } \\
\text { (10 months to } 99 \text { years) } \\
\text { and there was no } \\
\text { detectable correlation } \\
\text { between the mean } \\
\text { number of items returned } \\
\text { per patient and their age. }\end{array}$ \\
\hline 2008 & Bradley [64] & $\begin{array}{l}\text { United Kingdom; } \\
\text { Cumbria }\end{array}$ & $\begin{array}{l}\text { A medicine waste audit in community } \\
\text { pharmacies of Cumbria where each } \\
\text { pharmacy asked to analyse } 20 \text { returns of } \\
\text { unused medicines. Further qualitative data } \\
\text { were collected by interviewing the patients } \\
\text { and their representatives. }\end{array}$ & $\begin{array}{l}\text { Unused medicine were } \\
\text { returned to community } \\
\text { pharmacies in Cumbria } \\
\text { where each pharmacy was } \\
\text { asked to analyse } 20 \text { returns of } \\
\text { unused medicines. }\end{array}$ & $\begin{array}{l}\text { A total } 4563 \text { items was received } \\
\text { from } 87 \text { community } \\
\text { pharmacies across Cumbria. }\end{array}$ & Not studied. \\
\hline 2010 & Trueman et al. [6] & United Kingdom & $\begin{array}{l}\text { Unused medications returned to } 114 \\
\text { pharmacies ( } 51 \text { from London/urban, } 32 \text { from } \\
\text { North-West/rural and urban, } 24 \text { from } \\
\text { Yorkshire and Humber/rural and urban, } \\
7 \text { from West-Midlands/rural) from } 5 \text { primary } \\
\text { care trusts. }\end{array}$ & $\begin{array}{l}\text { Unused medicine were } \\
\text { returned to } 114 \text { pharmacies } \\
\text { in } 5 \text { primary care trusts. }\end{array}$ & $\begin{array}{l}\text { In total, } 8626 \text { items were } \\
\text { reported as returned with } 7500 \\
\text { of the returned items identified } \\
\text { and coded for analysis. }\end{array}$ & Not studied. \\
\hline
\end{tabular}


Table A1. Cont.

\begin{tabular}{|c|c|c|c|c|c|c|}
\hline Year of Study & Author(s) & Country/Settings & Research Instrument & $\begin{array}{c}\text { Wasted Medicines } \\
\text { Information (e.g., Take Back } \\
\text { Campaigns vs. Survey) }\end{array}$ & Sample & Demographics \\
\hline 2008 & Coma et al. [56] & Spain; Barcelona & $\begin{array}{l}\text { Unused medications returned to random } \\
\text { sample of } 118 \text { community pharmacies in } \\
\text { Barcelona invited to participate, } 38(32 \%) \\
\text { agreed to participate. Data were collected } \\
\text { from February to April 2005. Questionnaires } \\
\text { were completed by the returners. }\end{array}$ & $\begin{array}{l}\text { Unused medications were } \\
\text { collected from } 38 \text { community } \\
\text { pharmacies over a period of } 7 \\
\text { consecutive working days } \\
\text { (excluding Sundays). } \\
\text { A questionnaire was } \\
\text { designed to evaluate each } \\
\text { returned medicine. }\end{array}$ & $\begin{array}{l}\text { In total, } 1176 \text { packages were } \\
\text { returned by } 227 \text { patients. } \\
\text { The majority were medicines } \\
(96.6 \%) \text {, and the rest were } \\
\text { medical supplies or devices } \\
(0.5 \%) \text { or other products sold in } \\
\text { the community pharmacy } \\
\text { (2.9\%; e.g., personal care, } \\
\text { nutrition). Most medicines } \\
\text { returned were drugs for } \\
\text { human use ( } 99.8 \% \text { and only } \\
0.2 \% \text { were for veterinary use. }\end{array}$ & $\begin{array}{l}54.6 \% \text { women, } 64 \pm 20 \\
\text { years old. }\end{array}$ \\
\hline 2015 & Law et al. [46] & $\begin{array}{l}\text { U.S.A.; Southern } \\
\text { California }\end{array}$ & $\begin{array}{c}\text { Cross-sectional, observational two phases } \\
\text { study was conducted using a convenience } \\
\text { sample in Southern California. In Phase I, } \\
\text { a web-based survey was conducted at one } \\
\text { health sciences institution; and in Phase II, } \\
\text { a paper-based survey at drug take } \\
\text { back events. }\end{array}$ & Web and paper-based survey. & $\begin{array}{l}\text { Phase I: A total of } 539 \\
\text { prescription medications were } \\
\text { reported, with an average of } 4 \\
\text { per household. Approximately } \\
7 \% \text { of the unused medications } \\
\text { were expired, and } 30 \% \text { were } \\
\text { brand name. } \\
\text { Phase II: Of the } 776 \text { unused } \\
\text { medications returned for } \\
\text { disposal, } 311(40 \%) \\
\text { medications were brand name. } \\
\text { Nearly two-thirds }(66.2 \%) \text { were } \\
\text { expired, discontinued by the } \\
\text { physician ( } 25 \%) \text {, or became } \\
\text { unused after the patient } \\
\text { indicated feeling better }(17.6 \%) .\end{array}$ & $\begin{array}{l}\text { Phase I: Average } \\
\text { household age was } \\
36.4 \text { years, but not } \\
\text { described in Phase II } \\
\text { which the drug take back } \\
\text { program. }\end{array}$ \\
\hline 2004 & Garey et al. [25] & U.S.A.; Houston, Texas & $\begin{array}{l}\text { Unused medications returned to community } \\
\text { pharmacy during "Medicine Cabinet } \\
\text { Clean up } \\
\text { Campaign" over } 6 \text { months between April } \\
\text { and September } 2002 \text { (pilot study). }\end{array}$ & $\begin{array}{l}\text { "Medicine Cabinet Clean up } \\
\text { Campaign" }\end{array}$ & $\begin{array}{l}\text { In total, } 1315 \text { medication } \\
\text { containers were returned to the } \\
\text { community pharmacy. } 63 \% \text { of } \\
\text { returned medications were } \\
\text { dispensed between } 2000 \text { and } \\
2002,31 \% \text { from } 1995 \text { to } 1999 \\
\text { and } 6 \% \text { before } 1995 .\end{array}$ & Not studied. \\
\hline 2015 & Maeng et al. [34] & $\begin{array}{l}\text { U.S.A.; Regional health } \\
\text { plan in Central } \\
\text { Pennsylvania }\end{array}$ & $\begin{array}{l}\text { Telephone survey conducted by a survey } \\
\text { research centre. }\end{array}$ & Telephone survey. & Not studied. & Not studied. \\
\hline
\end{tabular}


Table A1. Cont.

\begin{tabular}{|c|c|c|c|c|c|c|}
\hline Year of Study & Author(s) & Country/Settings & Research Instrument & $\begin{array}{c}\text { Wasted Medicines } \\
\text { Information (e.g., Take Back } \\
\text { Campaigns vs. Survey) }\end{array}$ & Sample & Demographics \\
\hline 2014 & Vogler et al. [66] & Austria; Vienna & $\begin{array}{l}\text { Unused medications collected from } \\
\text { household garbage in all districts of Vienna } \\
\text { between } 12 \text { October and } 24 \text { November } 2009 .\end{array}$ & $\begin{array}{c}\text { Unused medicines ending } \\
\text { up in household garbage } \\
\text { were analysed in all districts } \\
\text { of Vienna. }\end{array}$ & $\begin{array}{c}\text { In total, } 152 \text { packs were } \\
\text { identified from manually } \\
\text { investigated sample from } \\
\text { household garbage in Vienna. }\end{array}$ & Not studied. \\
\hline 2013 & Chien et al. [71] & $\begin{array}{l}\text { Taiwan; Shuang-Ho } \\
\text { university teaching } \\
\text { hospital }\end{array}$ & $\begin{array}{c}\text { Discarded drugs were collected from the } \\
\text { Drug Discarding Bin at the Shuang-Ho } \\
\text { Hospital over } 4 \text { weeks. }\end{array}$ & $\begin{array}{l}\text { Discarded drugs from the } \\
\text { Drug Discarding Bin at the } \\
\text { Shuang-Ho Hospital in } \\
\text { Taiwan were collected and } \\
\text { analysed. A paper-based } \\
\text { questionnaire was utilised to } \\
\text { study the attitudes and } \\
\text { perspectives of the } \\
\text { out-patients and/or patients' } \\
\text { family members about } \\
\text { discarding unused } \\
\text { medications that were } \\
\text { prescribed and covered by } \\
\text { the National Health } \\
\text { Insurance policy. }\end{array}$ & $\begin{array}{l}\text { A total of } 98 \mathrm{~kg}(51,972) \\
\text { discarded medications } \\
\text { collected from the hospital } \\
\text { Drug Discarding Bin. }\end{array}$ & Not studied. \\
\hline 2013 & Abushanab et al. [48] & Jordan; Amman & $\begin{array}{l}\text { Cross sectional survey using a pre-piloted } \\
\text { questionnaire was used in the interview of } \\
219 \text { households in } 9 \text { areas of Amman to } \\
\text { about the types of drugs stored at home } \\
\text { conducted between November } 2009 \text { and } \\
\text { April } 2010 .\end{array}$ & Survey study. & $\begin{array}{l}\text { From the } 2393 \text { drug products } \\
\text { presented in surveyed } \\
\text { households, } 24.99 \% \text { was } \\
\text { considered as drug waste (drug } \\
\text { wastage, calculated as the sum } \\
\text { of drug products that had } \\
\text { expired } 10.91 \% \text {, had no clear } \\
\text { expiration date } 1.84 \% \text {, or which } \\
\text { had never been used since } \\
\text { dispensing } 15.04 \% \text { ). }\end{array}$ & $\begin{array}{l}\text { Age of the interviewee } \\
\text { (years) } 42.15 \pm 14.67 \text {. }\end{array}$ \\
\hline 2012 & Al-Azzam et al. [47] & $\begin{array}{l}\text { Jordan; North of Jordan } \\
\text { particularly Irbid }\end{array}$ & $\begin{array}{l}\text { Validated questionnaire was administered } \\
\text { to } 435 \text { households selected randomly from } \\
\text { different areas in the north of Jordan } \\
\text { (particularly in Irbid governorate) in the } \\
\text { period from April } 2007 \text { and until August } \\
2007 .\end{array}$ & Survey study. & $\begin{array}{l}\text { Of the total of } 2835 \text { medication } \\
\text { items found in the } 435 \text { selected } \\
\text { houses, } 65.3 \% \text { were in use, and } \\
34.7 \% \text { were not in use. }\end{array}$ & $\begin{array}{l}\text { Age of the interviewee } \\
\text { (years) } 36.4( \pm 11.9) \text {. }\end{array}$ \\
\hline
\end{tabular}


Table A1. Cont.

\begin{tabular}{|c|c|c|c|c|c|c|}
\hline Year of Study & Author(s) & Country/Settings & Research Instrument & $\begin{array}{c}\text { Wasted Medicines } \\
\text { Information (e.g., Take Back } \\
\text { Campaigns vs. Survey) }\end{array}$ & Sample & Demographics \\
\hline 2002 & Abou-Auda [27] & $\begin{array}{c}5 \text { regions in Saudi Arabia } \\
\text { and other Gulf countries } \\
\text { (Kuwait, U.A.E., Qatar, } \\
\text { and Oman) }\end{array}$ & $\begin{array}{l}\text { A questionnaire was administered to a total } \\
\text { of } 1641 \text { households participated in the study } \\
\text { (1554 in Saudi Arabia; } 87 \text { in other countries). }\end{array}$ & Survey study. & $\begin{array}{l}\text { A total of } 12,463 \text { drug products } \\
\text { were found in } 1554 \text { households } \\
\text { in Saudi Arabia. Among the } 87 \\
\text { households surveyed in the } 4 \\
\text { other Gulf countries, } 616 \text { drug } \\
\text { products were found. }\end{array}$ & Not studied. \\
\hline 2011 & Kheir et al. [51] & Qatar & $\begin{array}{l}\text { This was a cross-sectional, exploratory, } \\
\text { descriptive study. Households included in } \\
\text { the study were identified using a list of } \\
\text { home telephone numbers was selected } \\
\text { randomly from the telephone directory } \\
\text { maintained by Qtel }{ }^{\circledR}, \text { Qatar's national } \\
\text { telephone company. }\end{array}$ & Survey study. & $\begin{array}{l}\text { Four hundred and thirty-two } \\
\text { phone calls were made to } \\
\text { invite respondents to take part } \\
\text { in the study. Eighty-one } \\
\text { household representatives } \\
\text { initially expressed interest in } \\
\text { being part of the research } \\
\text { during the first call, of whom } \\
49 \text { participants (18\% of the } \\
\text { targeted sample size) answered } \\
\text { all survey questions. }\end{array}$ & Not reported. \\
\hline 2007 & Al-Siyabi et al. [60] & $\begin{array}{l}\text { Oman; Sultan Qaboos } \\
\text { University Hospital } \\
\text { (SQUH) }\end{array}$ & $\begin{array}{l}\text { Observational study of returned unused } \\
\text { medicines to the pharmacy at SQUH } \\
\text { between February and June 2003. }\end{array}$ & $\begin{array}{l}\text { Returned medicines received } \\
\text { by pharmacy staff were } \\
\text { analysed in the study. }\end{array}$ & $\begin{array}{l}\text { A total of } 1171 \text { items } \\
\text { (medications) were returned to } \\
\text { the pharmacy at SQUH; among } \\
\text { these, } 99 \text { drugs were excluded. } \\
\text { Medicines were included only } \\
\text { if they had SQUH patients' } \\
\text { labels, and any items without } \\
\text { SQUH patient' labels were } \\
\text { excluded from study. }\end{array}$ & Not studied. \\
\hline 2004 & Wongpoowarak et al. [20] & Thailand; Songkhla & $\begin{array}{l}\text { A cross-sectional survey of unused } \\
\text { medicines of a random sample of } 931 \\
\text { households in the Songkhla. Of the } 931 \\
\text { households surveyed and interviewed by } \\
\text { using a structured questionnaire, there were } \\
453(48.7 \%) \text { where at least one person } \\
\text { reported having unused medications. }\end{array}$ & Survey study. & $\begin{array}{l}\text { A total of } 1004 \text { unused } \\
\text { medication (items) were } \\
\text { identified from } 523 \\
\text { respondents who had unused } \\
\text { medications in } 453 \text { households. } \\
\text { Nine items could not be } \\
\text { identified because their } \\
\text { physical appearance did not } \\
\text { match that of any known } \\
\text { medication. Thus, } 995 \text { items } \\
\text { were included. }\end{array}$ & $\begin{array}{c}\text { Gender: } \\
\text { Male: } 224(42.8 \%) . \\
\text { Female: } 299(57.2 \%) . \\
\text { Age: } \\
\text { 0-9 years: } 167(31.9 \%) . \\
\text { 10-19 years: } 52(10.0 \%) . \\
20-29 \text { years: } 66(12.6 \%) \text {. } \\
\text { 30-39 years: } 76(14.5 \%) \text {. } \\
40-49 \text { years: } 64(12.2 \%) . \\
\text { 50-59 years: } 40(7.7 \%) . \\
\geq 60 \text { years: } 58(11.1 \%) .\end{array}$ \\
\hline
\end{tabular}


Table A1. Cont.

\begin{tabular}{|c|c|c|c|c|c|c|}
\hline Year of Study & Author(s) & Country/Settings & Research Instrument & $\begin{array}{c}\text { Wasted Medicines } \\
\text { Information (e.g., Take Back } \\
\text { Campaigns vs. Survey) }\end{array}$ & Sample & Demographics \\
\hline 2013 & Sooksriwong et al. [50] & $\begin{array}{l}\text { Thailand; } 4 \text { regions of } \\
\text { Thailand: Bangkok, } \\
\text { Chiang Mai, Khon Kaen, } \\
\text { Mahasarakham and } \\
\text { Songkla }\end{array}$ & $\begin{array}{l}\text { Structured questionnaire developed to } \\
\text { survey } 357 \text { households which were } \\
\text { interviewed and during January and March } \\
\text { 2011: } 46 \% \text { in Bangkok and } 54 \% \text { in } \\
\text { upcountry. }\end{array}$ & Survey study. & $\begin{array}{c}2208 \text { drug items were found in } \\
357 \text { households. } 952 \text { items } \\
(43 \%) \text { of these drug items were } \\
\text { dispensed by public hospitals, } \\
750 \text { items }(34 \%) \text { were from } \\
\text { drug stores, } 163 \text { items }(8 \%) \\
\text { were from private hospitals } \\
\text { and } 210 \text { items }(10 \%) \text { were from } \\
\text { others. }\end{array}$ & Not studied. \\
\hline 2011 & El-Hamamsy [26] & Egypt; Cairo & $\begin{array}{l}\text { Pilot study where all drugs returned unused } \\
\text { to } 20 \text { community pharmacies in Cairo over } \\
\text { period of one month (April 2009). }\end{array}$ & $\begin{array}{c}\text { All drugs returned unused } \\
\text { to } 20 \text { community pharmacies } \\
\text { located in Cairo, Egypt were } \\
\text { documented during April } \\
2009 . \\
\text { A total of } 316 \text { patients } \\
\text { completed a survey about } \\
\text { medication disposal } \\
\text { practices. }\end{array}$ & $\begin{array}{l}\text { A total of } 541 \text { drugs were } \\
\text { returned and collected over } \\
\text { one month. }\end{array}$ & Not studied. \\
\hline 2012 & Ibrahim et al. [49] & Egypt; Alexandria & $\begin{array}{l}\text { A cross-sectional descriptive study where all } \\
\text { drugs returned unused into randomly } \\
\text { selected } 60 \text { pharmacies in Alexandria over a } \\
\text { period of one month during March } 2011 .\end{array}$ & Survey study. & $\begin{array}{l}\text { A total of } 657 \text { drugs were } \\
\text { returned from } 600 \text { patients to } \\
\text { the } 60 \text { pharmacies over one } \\
\text { month. }\end{array}$ & $\begin{array}{l}\text { Males constituted the } \\
\text { higher percentage of the } \\
\text { participants } 56.7 \% \text {. } \\
\text { Elderly having } 60 \text { years } \\
\text { or above constituted the } \\
\text { highest proportion of the } \\
\text { sample }(28.3 \%) \text {, while the } \\
\text { lowest percentage (4.0\%) } \\
\text { was within the age group } \\
\text { (10 to less than } 20 \text { ). }\end{array}$ \\
\hline 2010 & Guirguis et al. [32] & $\begin{array}{l}\text { Australia; St Vincent's } \\
\text { Hospital, Melbourne }\end{array}$ & $\begin{array}{l}\text { Retrospective audit looked at all expired } \\
\text { medications or those no longer needed were } \\
\text { collected at St Vincent's Hospital, } \\
\text { Melbourne over } 2 \text { months (July and August } \\
\text { 2008). }\end{array}$ & $\begin{array}{l}\text { Retrospective audit looked } \\
\text { at all the items collected over } \\
\text { a period of } 2 \text { months: July } \\
\text { and August 2008. }\end{array}$ & $\begin{array}{l}\text { A total of } 293 \text { items were } \\
\text { collected from } 40 \text { patients } \\
\text { recruited over } 2 \text { months. }\end{array}$ & $\begin{array}{l}\text { Older than } 65 \text { years of } \\
\text { age. }\end{array}$ \\
\hline
\end{tabular}


Table A1. Cont.

\begin{tabular}{|c|c|c|c|c|c|c|}
\hline Year of Study & Author(s) & Country/Settings & Research Instrument & $\begin{array}{c}\text { Wasted Medicines } \\
\text { Information (e.g., Take Back } \\
\text { Campaigns vs. Survey) }\end{array}$ & Sample & Demographics \\
\hline 2014 & Kagashe et al. [57] & $\begin{array}{l}\text { Tanzania; tertiary } \\
\text { hospital in Dar } \\
\text { ES-Salaam city }\end{array}$ & $\begin{array}{l}\text { Cross-sectional study carried out at a } \\
\text { tertiary hospital in Dar es Salaam city } \\
\text { Tanzania where patient files were analysed } \\
\text { for last admission treatment information for } \\
\text { the year } 2012 .\end{array}$ & Survey study. & $\begin{array}{l}\text { About } 56.3 \% \text { of medicines } \\
\text { prescribed were dispensed to } \\
\text { patients. Out of the total } 1418 \\
\text { dispensed drugs, } 730 \\
\text { medicines were wasted. }\end{array}$ & $\begin{array}{l}\text { The mean age of the } \\
\text { study population was } \\
44 \text { years, with minimum } \\
\text { age of } 11 \text { years and } \\
\text { maximum of } 88 \text { years. } \\
\text { Medicines wastage was } \\
\text { reported from female } \\
\text { more than in male }(404 \\
(55.7 \%) \text { vs. } 326(47.1 \%), \\
\text { respectively). }\end{array}$ \\
\hline 2007 & Abahussain et al. [33] & Kuwait; Kuwait city & $\begin{array}{l}\text { Municipal collection program of unwanted } \\
\text { medicines from households in Kuwait City. }\end{array}$ & $\begin{array}{l}\text { Take back collection } \\
\text { program. }\end{array}$ & $\begin{array}{l}\text { Sample of } 200 \text { households in } \\
\text { Kuwait received an } \\
\text { educational letter and special } \\
\text { plastic bags in which to place } \\
\text { unwanted medicines to be } \\
\text { collected by the municipality. } \\
\text { A second convenience sample } \\
\text { of an additional } 14 \text { households } \\
\text { in Kuwait received the same } \\
\text { educational letter together with } \\
\text { a face-to-face interview and } \\
\text { assistance in collecting } \\
\text { unwanted medicines. }\end{array}$ & Not studied. \\
\hline 2013 & Aditya [43] & $\begin{array}{l}\text { India; dental hospital in } \\
\text { North India }\end{array}$ & $\begin{array}{l}\text { Descriptive cross-sectional survey of dental } \\
\text { students based on a structured } \\
\text { questionnaire format) was carried out in a } \\
\text { teaching dental hospital in North India. }\end{array}$ & Survey study. & $\begin{array}{l}244 \text { students, with } 8 \text { students } \\
\text { were excluded due to } \\
\text { incomplete forms only } 236 \\
\text { were included. }\end{array}$ & $\begin{array}{l}\text { Age of participants from } \\
20 \text { to } 40 \text { years. }\end{array}$ \\
\hline 2011 & Gupta et al. [42] & India; Greater Noida City & $\begin{array}{l}\text { A simple randomised prospective survey } \\
\text { study that was carried out for a period of six } \\
\text { months in selected areas of Greater Noida } \\
\text { City. Randomly selected } 102 \text { houses were } \\
\text { visited to educate and assess the people } \\
\text { about Home Medicine Cabinet. }\end{array}$ & Survey study. & $\begin{array}{l}\text { A total of } 392 \text { people were } \\
\text { surveyed in } 92 \text { houses with the } \\
\text { exception of } 10 \text { houses. }\end{array}$ & $\begin{array}{l}\text { Of the total } 392 \text { people } \\
\text { surveyed: } \\
\text { The male vs. female for } \\
\text { those with age }>12 \text { years } \\
\text { is } 144(36.73 \%) \text { vs. } 133 \\
(33.93 \%), \text { respectively. } \\
\text { The male vs. female for } \\
\text { those with age }<12 \text { years } \\
\text { is } 69(17.6 \%) \text { vs. } 46 \\
(11.74 \%), \text { respectively. }\end{array}$ \\
\hline
\end{tabular}


Table A1. Cont.

\begin{tabular}{|c|c|c|c|c|c|c|}
\hline Year of Study & Author(s) & Country/Settings & Research Instrument & $\begin{array}{c}\text { Wasted Medicines } \\
\text { Information (e.g., Take Back } \\
\text { Campaigns vs. Survey) }\end{array}$ & Sample & Demographics \\
\hline 2014 & Mirza and Ganguly [44] & $\begin{array}{l}\text { Anand district of Gujarat, } \\
\text { India }\end{array}$ & $\begin{array}{l}\text { A cross-sectional study was conducted } \\
\text { during 2012-2014. Data were collected from } \\
800 \text { houses, } 400 \text { each from urban and rural } \\
\text { areas and then analysed for the details of } \\
\text { medicines available in the house. }\end{array}$ & Survey study. & $\begin{array}{l}\text { A total of } 800 \text { houses, } 400 \text { each } \\
\text { from urban and rural areas, } \\
\text { were included for the study, } \\
\text { which was based on the } \\
\text { prevalence of self-medication } \\
\text { as per a previous study done in } \\
\text { India. }\end{array}$ & $\begin{array}{l}\text { The participants above } \\
\text { the age of } 18 \text { years, } \\
\text { capable of giving } \\
\text { information of medicine } \\
\text { use within the family (the } \\
\text { heads of the households } \\
\text { or their spouses or any } \\
\text { adult capable of } \\
\text { delivering required } \\
\text { information) were } \\
\text { interviewed for the study } \\
\text { The presence of any } \\
\text { healthcare professional } \\
\text { amongst the family } \\
\text { members in a visited } \\
\text { house was excluded in } \\
\text { order to avoid biased } \\
\text { answers. }\end{array}$ \\
\hline 2009 & Ali et al. [24] & Malaysia; Universiti Sains & $\begin{array}{l}\text { A prospective descriptive, cross-sectional } \\
\text { survey was conducted from February to } \\
\text { June } 2005 \text { in the Universiti Sains, Malaysia. }\end{array}$ & Survey study. & $\begin{array}{l}\text { A total of } 481 \text { single female } \\
\text { respondents were targeted for } \\
\text { a questionnaire-based survey } \\
\text { on randomly sampled students. } \\
\text { A total of } 1724 \text { different types } \\
\text { of medicines were found with } \\
\text { an average number of } 4 \\
\text { medicines found per student. }\end{array}$ & $\begin{array}{c}\text { Respondent were only } \\
\text { females ages varied from } \\
19 \text { to } 54 \text { years old. } 89.2 \% \\
(n=429) \text { of the students } \\
\text { were categorised in the } \\
19-24 \text { years age category, } \\
\text { while } 8.7 \%(n=42) \text { were } \\
\text { aged between } 25 \text { and } 30 \\
\text { years old. The remaining } \\
2.1 \%(n=10) \text { were aged } \\
\text { between } 31 \text { and } 54 \text { years. }\end{array}$ \\
\hline 2020 & Hassali and Shakeel [45] & Selangor, Malaysia & $\begin{array}{l}\text { The quantitative, cross-sectional study was } \\
\text { conducted by face-to-face interviews using a } \\
\text { pre-validated structured survey form in } \\
\text { Selangor, Malaysia from September to } \\
\text { December } 2019 \text {. }\end{array}$ & Survey study. & $\begin{array}{l}\text { Among the approached } 600 \\
\text { individuals, } 426 \text { showed their } \\
\text { willingness to participate in the } \\
\text { study. } \\
\text { Hence, the response rate of the } \\
\text { present study was } 71 \% \text {. }\end{array}$ & $\begin{array}{c}\text { A large proportion of the } \\
\text { respondents }(269 ; 63.1 \%) \\
\text { were females. Most of the } \\
\text { respondents were Malay } \\
\text { (378; } 88.7 \%) \text {, followed by } \\
\text { Chinese ( } 32 ; 7.5 \%) \text {. } \\
\text { The study population } \\
\text { included students, } \\
\text { private and public sector } \\
\text { employees, and } \\
\text { housewives, who were } \\
\text { over } 18 \text { years of age. } \\
\text { More than half of the } \\
\text { respondents were } \\
\text { bachelor's degree holders } \\
(220 ; 51.6 \%) .\end{array}$ \\
\hline
\end{tabular}


Table A1. Cont.

\begin{tabular}{|c|c|c|c|c|c|c|}
\hline Year of Study & Author(s) & Country/Settings & Research Instrument & $\begin{array}{c}\text { Wasted Medicines } \\
\text { Information (e.g., Take Back } \\
\text { Campaigns vs. Survey) }\end{array}$ & Sample & Demographics \\
\hline 2014 & Aboagye et al. [59] & Ghana & $\begin{array}{l}\text { The study was conducted over selected } \\
\text { areas in Ghana with a questionnaires were } \\
\text { randomly issued out from } 13 \text { to } 20 \\
\text { December } 2009 \text {. }\end{array}$ & Survey study. & $\begin{array}{l}\text { Out of the } 200 \text { questionnaires } \\
\text { sent out, } 180 \text { were retrieved } \\
\text { and analysed. }\end{array}$ & $\begin{array}{l}\text { The majority of the } \\
\text { respondents } 62.8 \% \\
(113 / 180) \text { were between } \\
\text { the ages of } 21 \text { and } 40 \\
\text { years, and the minority } \\
5.6 \%(10 / 180) \text { were above } \\
\text { 61years. A total of } 99 \\
\text { (55\%) of the respondents } \\
\text { were males } \\
\text { corresponding to } 81(45 \%) \\
\text { females. }\end{array}$ \\
\hline 2019 & Huang et al. [52] & $\begin{array}{l}\text { China, six provinces in } \\
\text { North, Central, and } \\
\text { Southern regions of } \\
\text { China }\end{array}$ & $\begin{array}{l}\text { A cross-sectional survey of } 625 \text { households } \\
\text { survey was carried out between March and } \\
\text { April } 2018 \text { in China. }\end{array}$ & Survey study. & $\begin{array}{l}\text { We randomly sampled } 1000 \\
\text { households from the } \\
\text { communities } \\
\text { according to community } \\
\text { population information } \\
\text { registration forms. At the end } \\
\text { of the period, after removal of } \\
\text { incomplete responses, a total of } \\
625 \text { completed and usable } \\
\text { questionnaires were received, } \\
\text { equating to a response rate of } \\
62.5 \%(625 / 1000) \text {. }\end{array}$ & $\begin{array}{l}\text { The majority of } \\
\text { respondents, } 61.9 \% \\
\text { ( } 387 / 625) \text { in the } \\
\text { households visited were } \\
\text { females. A high } \\
\text { proportion } 60.6 \% \\
\text { ( } 379 / 625) \text { of the } \\
\text { respondents were } \\
\text { employees from different } \\
\text { companies. In terms of } \\
\text { age groups, } 78.4 \% \\
\text { (490/625) of respondents } \\
\text { were less than } 30 \text { years } \\
\text { old, and } 12.0 \% \text { ( } 75 / 625) \text { of } \\
\text { the respondents were } \\
\text { aged between } 31 \text { and } 45 \text {. }\end{array}$ \\
\hline 2019 & Vella and West [58] & Malta, Maltese village & $\begin{array}{l}\text { The study was conducted from } 1 \text { April to } 31 \\
\text { December } 2018 \text { within a community } \\
\text { pharmacy in a small Maltese village with } \\
3500 \text { inhabitants. }\end{array}$ & Survey study. & $\begin{array}{l}\text { A total of } 411 \text { medications were } \\
\text { collected, amounting to a total } \\
\text { cost of approximately } € 2600 .\end{array}$ & Not reported. \\
\hline
\end{tabular}


Table A1. Cont.

\begin{tabular}{|c|c|c|c|c|c|c|}
\hline Year of Study & Author(s) & Country/Settings & Research Instrument & $\begin{array}{c}\text { Wasted Medicines } \\
\text { Information (e.g., Take Back } \\
\text { Campaigns vs. Survey) }\end{array}$ & Sample & Demographics \\
\hline 2020 & Insani et al. [54] & Bandung, Indonesia & $\begin{array}{l}\text { A descriptive cross-sectional study was } \\
\text { conducted in Bandung, Indonesia, from } \\
\text { November 2017-January } 2018 .\end{array}$ & Survey study. & $\begin{array}{l}\text { A total of } 497 \text { respondents } \\
\text { completed the questionnaire. }\end{array}$ & $\begin{array}{c}\text { A total of } 497 \\
\text { respondents completed } \\
\text { the questionnaire of } \\
\text { which many were female } \\
(n=366,73.6 \%) \text { and aged } \\
\text { between } 18 \text { and } 30 \text { years } \\
(n=424,85.3 \%) \text {. More } \\
\text { than half of them } \\
\text { completed secondary } \\
\text { education }(n=326,65.6 \%) \\
\text { and about one-third ( } n= \\
167,33.6 \%) \text { were } \\
\text { university graduates. A } \\
\text { large proportion of } \\
\text { respondents were } \\
\text { students/university } \\
\text { students }(n=342,69.0 \%) .\end{array}$ \\
\hline 2010 & Jassim [53] & Basrah, Iraq & $\begin{array}{l}\text { This is a descriptive study involving a } \\
\text { questionnaire survey to determine the } \\
\text { extent of drug storage and self-medication } \\
\text { in } 300 \text { household units Basrah, Iraq between } \\
2007 \text { and } 2008 \text {. }\end{array}$ & Survey study. & $\begin{array}{l}\text { A total of } 300 \text { household units } \\
\text { in Basrah, Iraq included in this } \\
\text { study. A survey was conducted } \\
\text { in } 300 \text { households in Basrah, } \\
\text { southern Iraq to determine the } \\
\text { availability, source, and storage } \\
\text { conditions of medicinal drugs } \\
\text { and the prevalence of } \\
\text { self-medication with } \\
\text { antimicrobials. }\end{array}$ & Not reported. \\
\hline 2012 & Auta et al. [55] & Nigeria & $\begin{array}{l}\text { A cross-sectional survey of a random } \\
\text { sample of } 240 \text { undergraduate pharmacy } \\
\text { students of the University of Jos, Jos, } \\
\text { Nigeria, was carried out. }\end{array}$ & Survey study. & $\begin{array}{l}\text { A total of } 240 \text { students were } \\
\text { chosen randomly with at least } \\
50 \text { from each professional } \\
\text { level/year to participate in the } \\
\text { study. A pre-tested, } \\
\text { self-administered } \\
\text { questionnaire was distributed } \\
\text { among participants after } \\
\text { explaining the purpose of the } \\
\text { study and obtaining oral } \\
\text { informed consent. }\end{array}$ & $\begin{array}{l}\text { A total of } 188 \text { of the } 240 \\
\text { (representing } 78.3 \% \text { ) } \\
\text { questionnaires } \\
\text { administered were } \\
\text { completely filled and } \\
\text { returned by respondents. } \\
\text { The respondents } \\
\text { consisted of } 55.3 \% \text { males } \\
\text { and } 44.7 \% \text { females with } \\
\text { the majority of the } \\
\text { respondents between the } \\
\text { ages of } 21 \text { and } 25 \text { years. }\end{array}$ \\
\hline
\end{tabular}


Table A1. Cont.

\begin{tabular}{|c|c|c|c|c|c|c|}
\hline Year of Study & Author(s) & Country/Settings & Research Instrument & $\begin{array}{c}\text { Wasted Medicines } \\
\text { Information (e.g., Take Back } \\
\text { Campaigns vs. Survey) }\end{array}$ & Sample & Demographics \\
\hline 2015 & Wondimu et al. (41) & $\begin{array}{c}\text { Tigray Region, Northern } \\
\text { Ethiopia }\end{array}$ & $\begin{array}{l}\text { A community-based cross-sectional study } \\
\text { was conducted in April } 2013 \text { in Tigray } \\
\text { Region, Ethiopia. }\end{array}$ & Survey study. & $\begin{array}{c}\text { A total of } 1034 \text { participants } \\
\text { were enrolled in the study. A } \\
\text { multi-stage sampling method } \\
\text { was employed to select } \\
\text { households. }\end{array}$ & $\begin{array}{c}\text { Overall, } 1000(97 \%) \\
\text { households responded to } \\
\text { the interview, among } \\
\text { them } 504 \text { urban and } 496 \\
\text { were rural. The median } \\
\text { family size of the } \\
\text { households was } 5 ; \text { just } \\
\text { above half }(52 \%) \text { of the } \\
\text { households had at least } \\
\text { five family members. } \\
\text { Only } 7 \% \text { of the surveyed } \\
\text { households had a health } \\
\text { professional as a family } \\
\text { member. }\end{array}$ \\
\hline 2017 & Teni et al. [36] & $\begin{array}{c}\text { Gondar town, } \\
\text { northwestern Ethiopia }\end{array}$ & $\begin{array}{l}\text { A cross-sectional household survey was } \\
\text { conducted from } 5 \text { April to } 6 \text { May 2015. In } \\
\text { the study, } 809 \text { households were surveyed } \\
\text { from four sub-cities selected through } \\
\text { multi-stage sampling with } 771 \text { included in } \\
\text { the final analysis. }\end{array}$ & Survey study. & $\begin{array}{l}\text { In the study, } 809 \text { households } \\
\text { were surveyed from four } \\
\text { sub-cities selected through } \\
\text { multi-stage sampling with } 771 \\
\text { included in the final analysis. }\end{array}$ & $\begin{array}{l}\text { Of the participants of the } \\
\text { study that represented } \\
\text { their respective } \\
\text { households, upwards of } \\
\text { three quarters }(76.3 \%) \\
\text { and two-fifths ( }(40.9 \%) \\
\text { were female and those in } \\
\text { the age group of } 18 \text { to } 29 \\
\text { years, respectively. } \\
\text { Nearly three-fourths } \\
(73.3 \% \text { ) followed } \\
\text { Orthodox Christianity, } \\
\text { and almost all (90.3) were } \\
\text { Amhara in their ethnic } \\
\text { identity. }\end{array}$ \\
\hline
\end{tabular}


Table A1. Cont.

\begin{tabular}{|c|c|c|c|c|c|c|}
\hline Year of Study & Author(s) & Country/Settings & Research Instrument & $\begin{array}{c}\text { Wasted Medicines } \\
\text { Information (e.g., Take Back } \\
\text { Campaigns vs. Survey) }\end{array}$ & Sample & Demographics \\
\hline 2019 & Ebrahim et al. [37] & $\begin{array}{l}\text { Awi zone, Amhara } \\
\text { regional state, Ethiopia }\end{array}$ & $\begin{array}{c}\text { A facility-based cross-sectional study design } \\
\text { supplemented by a qualitative approach } \\
\text { was conducted from } 23 \text { April to } 22 \text { May } \\
2018 .\end{array}$ & Survey study. & $\begin{array}{l}\text { A total of } 4 \text { health facilities } \\
\text { were included in the study. } \\
\text { During the } 1 \text { month of the } \\
\text { study period, } 56 \text { types of } \\
\text { medications were found } \\
\text { unused at the health facilities. }\end{array}$ & $\begin{array}{l}\text { Three of the heads were } \\
\text { male and one was a } \\
\text { female. All of them were } \\
\text { BSc nurses with a work } \\
\text { experience of a minimum } \\
\text { of } 4.6 \text { and a maximum of } \\
8 \text { years. All the pharmacy } \\
\text { heads were male and } \\
\text { degree holders with a } \\
\text { minimum experience of } 4 \\
\text { years and maximum } \\
\text { experience of } 8 \text { years. A } \\
\text { total of } 3 \text { store women } \\
\text { and } 1 \text { store man were } \\
\text { interviewed. All the store } \\
\text { men/women were } \\
\text { diploma holders with a } \\
\text { work experience of a } \\
\text { minimum of } 4 \text { years and } \\
\text { a maximum of } 8 \text { years. }\end{array}$ \\
\hline 2020 & Gudeta and Assefa [39] & Jimma city, Ethiopia & $\begin{array}{l}\text { A facility-based descriptive cross-sectional } \\
\text { study was conducted among private } \\
\text { practitioners in retail outlets of Jimma city } \\
\text { from } 20 \text { November to } 19 \text { December } 2018 .\end{array}$ & Survey study. & $\begin{array}{l}\text { All drug shops, } 35(62.5 \%) \text { and } \\
\text { pharmacies, } 21(37.5 \%) \text { in } \\
\text { Jimma city, were visited, } 3 \text { of } \\
\text { which were used for } \\
\text { pre-testing. A total of } 106 \\
\text { questionnaires were } \\
\text { distributed to practitioners in } \\
53 \text { retail outlets, of which } 87 \\
\text { returned the completed } \\
\text { questionnaires, making a } \\
\text { response rate of } 82.1 \% \text {. }\end{array}$ & $\begin{array}{l}\text { The majority of the } \\
\text { practitioners, } 44(50.6 \%) \\
\text { were within the age range } \\
\text { of } 25 \text { to } 31 \text { years. More } \\
\text { than half, } 56(64.4 \%) \text { of } \\
\text { them were males. } \\
\text { Regarding their } \\
\text { profession, the majority } \\
\text { of them were pharmacy } \\
\text { professionals, } 73(83.9 \%) .\end{array}$ \\
\hline
\end{tabular}


Table A1. Cont.

\begin{tabular}{|c|c|c|c|c|c|c|}
\hline Year of Study & Author(s) & Country/Settings & Research Instrument & $\begin{array}{c}\text { Wasted Medicines } \\
\text { Information (e.g., Take Back } \\
\text { Campaigns vs. Survey) }\end{array}$ & Sample & Demographics \\
\hline 2020 & Kahsay et al. [40] & Adigrat city, Ethiopia & $\begin{array}{l}\text { A cross-sectional study was conducted } \\
\text { using semistructured questionnaires, which } \\
\text { focussed on knowledge, attitudes, and } \\
\text { disposal practices for unused and expired } \\
\text { medications were used to collect data from } \\
\text { respondents. }\end{array}$ & Survey study. & $\begin{array}{l}\text { The study was conducted } \\
\text { among } 359 \text { respondents from } \\
\text { the residents of Adigrat city, } \\
\text { Ethiopia. All of the } 359 \\
\text { returned questionnaires were } \\
\text { valid for data entry and } \\
\text { analysis. }\end{array}$ & $\begin{array}{c}\text { All the approached } 359 \\
\text { individuals agreed to } \\
\text { participate in the study. } \\
\text { Of the } 359 \text { respondents, } \\
207(57.7 \%) \text { were males. } \\
\text { The majority (137; } 38.2 \%) \\
\text { of the respondents were } \\
32 \text { years old and above. } \\
\text { Concerning their } \\
\text { educational level, one } \\
\text { hundred and twelve } \\
\text { (31.2\%) respondents } \\
\text { completed secondary } \\
\text { education, } 178 \text { (49.6\%) } \\
\text { had a college/university } \\
\text { degree and above, and } 31 \\
\text { (8.6\%) were illiterate. }\end{array}$ \\
\hline 2020 & Yimenu et al. [38] & $\begin{array}{l}\text { Awi zone, Amhara } \\
\quad \text { regional state, } \\
\text { Northwestern Ethiopia }\end{array}$ & $\begin{array}{l}\text { A community-based cross-sectional study } \\
\text { was conducted through interviews with } \\
\text { representatives of households. }\end{array}$ & Survey study. & $\begin{array}{l}\text { A total of } 23 \text { kebeles (the } \\
\text { smallest an administrative unit } \\
\text { in Ethiopia) ( } 2 \text { urban and } 21 \\
\text { rural kebeles) from four } \\
\text { woredas were selected using a } \\
\text { multi-stage sampling } \\
\text { technique. A total of } 507 \\
\text { households were included in } \\
\text { the study. }\end{array}$ & $\begin{array}{l}\text { The majority of the study } \\
\text { participants, } 368(72.6 \%), \\
\text { were female. The mean } \\
\text { age of the study } \\
\text { participants was } 40 \text { years } \\
\text { and the majority were } \\
\text { between the ages of } 30 \\
\text { and } 65(67.9 \%)\end{array}$ \\
\hline 2020 & Yimenu et al. [38] & $\begin{array}{l}\text { Awi zone, Amhara } \\
\text { regional state, } \\
\text { Northwestern Ethiopia }\end{array}$ & $\begin{array}{l}\text { A community-based cross-sectional study } \\
\text { was conducted through interviews with } \\
\text { representatives of households. }\end{array}$ & Survey study. & $\begin{array}{l}\text { A total of } 23 \text { kebeles (the } \\
\text { smallest an administrative unit } \\
\text { in Ethiopia) ( } 2 \text { urban and } 21 \\
\text { rural kebeles) from four } \\
\text { woredas were selected using a } \\
\text { multi-stage sampling } \\
\text { technique. A total of } 507 \\
\text { households were included in } \\
\text { the study. }\end{array}$ & $\begin{array}{l}\text { The majority of the study } \\
\text { participants, } 368(72.6 \%), \\
\text { were female. The mean } \\
\text { age of the study } \\
\text { participants was } 40 \text { years } \\
\text { and the majority were } \\
\text { between the ages of } 30 \\
\text { and } 65(67.9 \%)\end{array}$ \\
\hline
\end{tabular}


Table A2. Summary of the therapeutic classes, dosage forms, and limitations of the included studies.

\begin{tabular}{|c|c|c|c|c|c|}
\hline Year of Study & Author(s) & Settings/Country & Therapeutic Category of the Unused, Wasted Medicine & Dosage Form & Study Limitation \\
\hline 2015 & Gracia-Vásquez et al. [61] & $\begin{array}{l}\text { Mexico; nine cities of } \\
\text { Monterrey }\end{array}$ & $\begin{array}{c}\text { The most commonly returned medications were of } \\
\text { nonsteroidal anti-inflammatory followed by cardiovascular } \\
\text { drugs. Nonsteroidal anti-inflammatory drugs: } 16.11 \% \text {. } \\
\text { Cardiovascular drugs: } 14.21 \% \text { (Anti-hypertensive } 55 \% \text { ). } \\
\text { Gastrointestinal drugs } 11.43 \% \text {. Antibacterial drugs: } 10.05 \% \text {. } \\
\text { Respiratory system drugs: } 8.75 \% \text {. Neurological drugs: } \\
\text { 6.13\% (anti-depressant: } 34 \% \text { ). Dietary supplement: } 5.23 \% \text {. } \\
\text { Anti-diabetic drugs: } 4.34 \% \text {. Miscellaneous drugs: } 3.79 \% \text {. } \\
\text { Hypolipemic drugs: } 3.67 \% \text {. Anti-parasitic drugs: } 2.48 \% \text {. } \\
\text { Hormonal drugs: } 1.89 \% \text {. Anti-micotic drugs: } 1.84 \% \text {. } \\
\text { Steroidal anti-inflammatory drugs: } 1.72 \% \text {. Dermatological } \\
\text { drugs: } 1.71 \% \text {. Ophthalmic drugs: } 1.64 \% \text {. Anti-viral drugs: } \\
1.53 \% \text {. }\end{array}$ & $\begin{array}{l}\text { The majority of unused/expired } \\
\text { medications collected (73\%) was in } \\
\text { solid dosage form (tablets, capsules, } \\
\text { granules, powders, and lozenges). } \\
20 \% \text { were liquid pharmaceutical } \\
\text { forms (syrups, injections, eye drops, } \\
\text { suspensions, emulsions, and lotions). } \\
6 \% \text { were semisolid (ointments, } \\
\text { creams, gel, paste, and suppositories). } \\
1 \% \text { were other forms, such as } \\
\text { metered dose inhalers, sprays, } \\
\text { patches, strips, and chewing gums. }\end{array}$ & $\begin{array}{l}\text { Unable to describe } \\
\text { respondent demographic } \\
\text { information. }\end{array}$ \\
\hline 2008 & Braund et al. [21] & New Zealand & $\begin{array}{l}\text { The most commonly returned medications were of the } \\
\text { nervous system drugs, followed by alimentary tract and } \\
\text { metabolism. Nervous system drugs: } 17 \% \text {. Alimentary tract } \\
\text { and metabolism system drugs: } 14 \% \text {. Cardiovascular system } \\
\text { drugs: } 12 \% \text {. Respiratory system and allergies: } 11 \% \text {. } \\
\text { Musculoskeletal system drugs: } 11 \% \text {. Infections - agents for } \\
\text { systemic use: } 9 \% \text {. Blood and blood-forming organs: } 8 \% \text {. } \\
\text { Oncology agents and immunosuppressants: } 6 \% \text {. } \\
\text { Genitourinary system: } 5 \% \text {. Dermatologicals: } 3 \% \text {. Sensory } \\
\text { organs: } 2 \% \text {. Hormone preparations-systemic: } 2 \% \text {. }\end{array}$ & Only oral dosage form reported. & $\begin{array}{l}\text { Small number of returned } \\
\text { unused medication. }\end{array}$ \\
\hline 2009 & Braund et al. [31] & $\begin{array}{l}\text { New Zealand; Hutt Valley } \\
\text { District Health Board }\end{array}$ & $\begin{array}{l}\text { The predominant therapeutic group was drugs affecting the } \\
\text { nervous system, but individually, diclofenac sodium and } \\
\text { ibuprofen were the most returned medications, respectively. } \\
\text { Nervous system drugs: } 19 \% \text {. Alimentary tract and } \\
\text { metabolism: } 13 \% \text {. Cardiovascular system: } 12 \% \text {. } \\
\text { Musculoskeletal system: } 11 \% \text {. Respiratory system and } \\
\text { allergies, and miscellaneous: } 8 \% \text {. Blood and blood-forming } \\
\text { organs: } 7 \% \text {, Dermatological and anti-infective: } 7 \% \text {. } \\
\text { Genitourinary: } 3 \% \text {, Hormones: } 3 \% \text {. }\end{array}$ & $\begin{array}{l}\text { Oral solid forms (tablets and } \\
\text { capsules) were counted. Liquid } \\
\text { medications were quantified by the } \\
\text { amount left in the original container, } \\
\text { semisolid preparations were } \\
\text { estimated as a proportion of original } \\
\text { container. Inhalers were recorded as } \\
\text { either full, half-full, or empty. } \\
\text { Anything almost empty was } \\
\text { excluded from the analysis. }\end{array}$ & $\begin{array}{l}\text { The chosen sample of the } \\
\text { total returned unused } \\
\text { medicine was around } \\
20 \% \text {, which maybe not } \\
\text { representative of the } \\
\text { whole sample. }\end{array}$ \\
\hline
\end{tabular}


Table A2. Cont.

\begin{tabular}{|c|c|c|c|c|c|}
\hline Year of Study & Author(s) & Settings/Country & Therapeutic Category of the Unused, Wasted Medicine & Dosage Form & Study Limitation \\
\hline 2010 & Caroline et al. [29] & $\begin{array}{l}\text { New Zealand; Nelson } \\
\text { Bays region }\end{array}$ & $\begin{array}{c}\text { The most common returned (top 20) by quantities } \\
\text { (individual unit) were }(n=435,397): \text { Salazopyrin: } 94,271 \\
\text { tablets. Paracetamol: } 23,251 \text { tablets. Lactulose: } 11,324 \mathrm{~mL} \text {. } \\
\text { Aspirin: } 10,047 \text { tablets. Simvastatin: } 7380 \text { tablets. } \\
\text { Diclofenac: } 7014 \text { (mixed preparation). Prednisolone: } 7004 \\
\text { tablets. Metoprolol: } 6627 \text { tablets. Warfarin: } 6590 \text { tablets. } \\
\text { Furosemide: } 6117 \text { tablets. Lemnis fatty cream: } 6095 \mathrm{~g} \text {. } \\
\text { Cilazapril: } 5687 \text { tablets. (Paracetamol and codeine) } \\
\text { preparation: } 5003 \text { tablets. Ibuprofen: } 4873 \text { tablets. Codeine: } \\
4794 \text { tablets. Laxsol: } 4267 \text { tablets. Morphine: } 4107 \text { (mixed } \\
\text { preparations). Emulsifying ointment: } 4030 \text { g. Quinapril: } \\
3890 \text { tablets. }\end{array}$ & $\begin{array}{l}\text { Oral solid forms (tablets and } \\
\text { capsules) with tablets as the most } \\
\text { common returned dosage form. } \\
\text { Oral liquid forms. } \\
\text { Cream and ointment. }\end{array}$ & $\begin{array}{l}\text { Unable to describe } \\
\text { respondent demographic } \\
\text { information. }\end{array}$ \\
\hline 2009 & James et al. [65] & $\begin{array}{l}\text { New Zealand: Taranaki } \\
\text { region (around 37,000 } \\
\text { households) }\end{array}$ & $\begin{array}{l}\text { The predominant therapeutic group was drugs affecting the } \\
\text { nervous system, but individually, paracetamol } \\
\text { (acetaminophen) was the most returned medication } \\
\text { respectively. Nervous system drugs ( } n=658,24.3 \%) \text {. } \\
\text { Cardiovascular system }(n=559,20.7 \% \text { ). Alimentary tract } \\
\text { and metabolism }(n=529,19.6 \%) \text {. Blood and blood-forming } \\
\text { organs }(n=283,10.5 \%) \text {. Respiratory system and allergies }(n \\
=190,7.1 \%) .\end{array}$ & Not studied. & $\begin{array}{c}\text { Unable to describe } \\
\text { respondent demographic } \\
\text { information. } \\
\text { In addition, due the } \\
\text { different policies for } \\
\text { collection and disposal of } \\
\text { medicines, the majority of } \\
\text { unused medicines were } \\
\text { disposed into landfills } \\
\text { and water system, which } \\
\text { may mean that the } \\
\text { returned amount may be } \\
\text { underestimate of the } \\
\text { extent of unused } \\
\text { medicines. }\end{array}$ \\
\hline 2005 & Langley et al. [62] & $\begin{array}{l}\text { United Kingdom; East } \\
\text { Birmingham }\end{array}$ & $\begin{array}{l}\text { The predominant therapeutic group was drugs affecting } \\
\text { cardiovascular system. Cardiovascular system drugs: } \\
28.5 \% \text {. Central nervous system drugs: } 18.8 \% \text {. Respiratory } \\
\text { system drugs: } 14.7 \% \text {. Gastrointestinal drugs: } 10.6 \% \text {. } \\
\text { Endocrine system drugs: } 5.6 \% \text {. Musculoskeletal and joint } \\
\text { disease drugs: } 5 \% \text {. Anti-infective Drugs: } 4.7 \% \text {. Eye Drugs: } \\
3.5 \% \text {. Nutrition and blood drugs: } 2.1 \% \text {. Skin drugs: } 1.8 \% \text {. } \\
\text { Obstetrics, gynaecology, and urinary tract disorders: } 1.5 \% \text {. } \\
\text { Nutrition and blood and unknown: } 1.2 \% \text {. Malignant } \\
\text { disease and immunosuppression: } 0.9 \% \text {. }\end{array}$ & $\begin{array}{l}\text { Tablet or capsule, oral liquid, cream } \\
\text { or ointment, and inhalers. }\end{array}$ & $\begin{array}{l}\text { Sample size and the } \\
\text { number of returns are } \\
\text { small, which makes it } \\
\text { difficult to extrapolate the } \\
\text { result to the whole United } \\
\text { Kingdom. }\end{array}$ \\
\hline
\end{tabular}


Table A2. Cont.

\begin{tabular}{|c|c|c|c|c|c|}
\hline Year of Study & Author(s) & Settings/Country & Therapeutic Category of the Unused, Wasted Medicine & Dosage Form & Study Limitation \\
\hline 2007 & Mackridge et al. [63] & $\begin{array}{l}\text { United Kingdom; Eastern } \\
\text { Birmingham Primary } \\
\text { Care Trust (P.C.T.) }\end{array}$ & $\begin{array}{l}\text { The predominant therapeutic groups were drugs affecting } \\
\text { cardiovascular system and drugs acting on the central } \\
\text { nervous system, respectively. The most commonly returned } \\
\text { drugs were aspirin (102 items), co-codamol ( } 98 \text { items), } \\
\text { salbutamol ( } 96 \text { items), furosemide ( } 90 \text { items), and glyceryl } \\
\text { trinitrate ( } 78 \text { items). Drugs affecting cardiovascular system } \\
\text { (1003 items, } 26.6 \%) \text {. Drugs acting on the central nervous } \\
\text { system ( } 884 \text { items, } 23.5 \%) \text {. Drugs affecting respiratory } \\
\text { system }(358 \text { items, } 9.5 \%) \text { and gastrointestinal system ( } 358 \\
\text { items, } 9.5 \%) \text {. Drugs affecting endocrine system ( } 257 \text { items, } \\
6.8 \%) \text {. Drugs treating musculoskeletal and joint diseases } \\
(235 \text { items, } 6.2 \%) \text {. Anti-infective drugs ( } 165 \text { items, } 4.4 \%) \text {. } \\
\text { Drugs for skin (124 items, 3.3\%). Drugs for nutrition and } \\
\text { blood ( }(116 \text { items, 3.1\%). Drugs for eye ( } 65 \text { items, } 1.7 \%) \text {. } \\
\text { Obstetrics, gynaecology, and urinary tract disorders (59 } \\
\text { items, } 1.6 \%) \text {. Drugs for ear, nose, and oropharynx ( } 58 \text { items, } \\
1.5 \%) \text { and others ( } 58 \text { items, } 1.5 \%) \text {. Drugs for malignant } \\
\text { disease and immunosuppression } 20 \text { items, } 0.5 \%) \text {. Drugs for } \\
\text { anaesthesia ( } 5 \text { items, } 0.1 \%) \text {. }\end{array}$ & $\begin{array}{l}\text { Tablet or capsule, oral liquid, cream } \\
\text { or ointment, and inhalers. }\end{array}$ & $\begin{array}{l}\text { The author reported that } \\
\text { this study did not attempt } \\
\text { to estimate the quantities } \\
\text { of unused medicines at } \\
\text { patient's home; as a result, } \\
\text { it is more likely that the } \\
\text { unused medicines from } \\
\text { primary care was } \\
\text { underestimated. }\end{array}$ \\
\hline 2008 & Bradley [64] & $\begin{array}{l}\text { United Kingdom; } \\
\text { Cumbria }\end{array}$ & $\begin{array}{l}\text { The greatest value of returned of medicines was from } \\
\text { cardiovascular and central nervous system categories } \\
\text { (BNF), total number of returns }(n=4562) \text { : Cardiovascular } \\
(n=1232) \text {. Central nervous system }(n=1149) \text {. } \\
\text { Gastrointestinal system }(n=468) \text { Endocrine }(n=334) \text {. } \\
\text { Respiratory }(n=307) \text {. Anti-infective }(n=250) \text {. } \\
\text { Musculoskeletal and joint }(n=228) \text {. Nutrition and blood }(n \\
\quad=141) \text {. Skin }(n=134) \text {. Others }(n=319)\end{array}$ & Not studied. & $\begin{array}{l}\text { It is an audit report with a } \\
\text { result from } \\
\text { Cumbria/northwest of } \\
\text { England, which may not } \\
\text { representative of the } \\
\text { whole United Kingdom } \\
\text { and may underestimate } \\
\text { the extent of unused } \\
\text { medicines. }\end{array}$ \\
\hline 2010 & Trueman et al. [6] & United Kingdom & 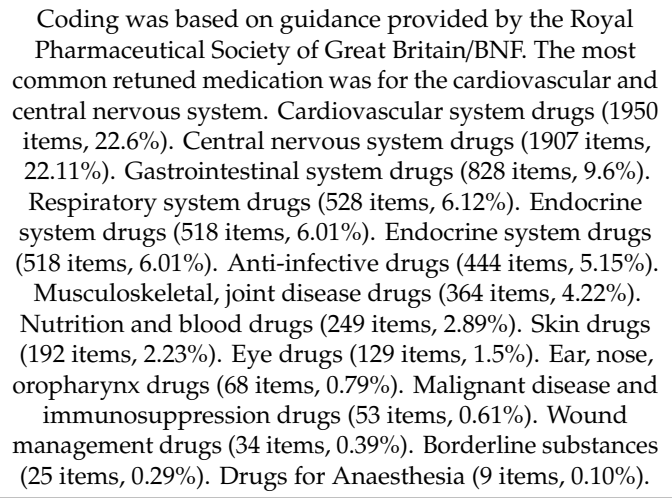 & Not studied. & $\begin{array}{l}\text { Unable to describe } \\
\text { respondent demographic } \\
\text { information. }\end{array}$ \\
\hline
\end{tabular}


Table A2. Cont.

\begin{tabular}{|c|c|c|c|c|c|}
\hline Year of Study & Author(s) & Settings/Country & Therapeutic Category of the Unused, Wasted Medicine & Dosage Form & Study Limitation \\
\hline 2008 & Coma et al. [56] & Spain; Barcelona & 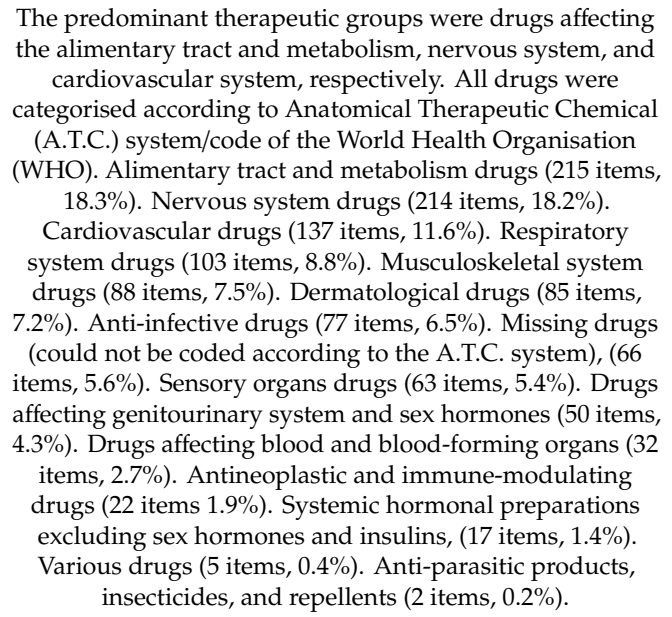 & Not studied. & $\begin{array}{l}\text { Unable to describe the } \\
\text { respondent demographic } \\
\text { information clearly. }\end{array}$ \\
\hline 2015 & Law et al. [46] & $\begin{array}{l}\text { U.S.A.; Southern } \\
\text { California }\end{array}$ & $\begin{array}{l}\text { Approximately } 2 \text { of } 3 \text { prescription medications were } \\
\text { reported unused. In Phase I, pain medications ( } 23.3 \% \text { ) and } \\
\text { antibiotics ( } 18 \% \text { ) were most commonly reported as unused. } \\
\text { In Phase II, } 17 \% \text { of medications for chronic conditions } \\
\text { (hypertension, diabetes, cholesterol, heart disease) and } 8.3 \% \\
\text { for mental health problems } \\
\text { (antidepressants/antipsychotic/anti-convulsant) were } \\
\text { commonly reported as unused. } 7 \% \text { painkillers and } 4 \% \\
\text { electrolytes and dietary supplements. }\end{array}$ & $\begin{array}{l}\text { Tablets, pills, capsules, and liquid } \\
\text { preparations. }\end{array}$ & $\begin{array}{l}\text { Use of a web-based survey } \\
\text { may limit the accessibility } \\
\text { of this study to people } \\
\text { without computer and } \\
\text { Internet access at home, } \\
\text { which may to some extent } \\
\text { underestimate the extent } \\
\text { of unused medicines. } \\
\text { Unable to describe } \\
\text { respondent demographic } \\
\text { information. }\end{array}$ \\
\hline 2004 & Garey et al. [25] & U.S.A.; Houston, Texas & $\begin{array}{c}\text { The predominant therapeutic group was nonsteroidal } \\
\text { anti-inflammatory drugs/pain. Nonsteroidal } \\
\text { anti-inflammatory drugs/pain } 25 \% \text {. Drugs for } \\
\text { cough/cold/allergy 15\%. Anti-infective drugs } 11 \% \text {. } \\
\text { Cardiovascular drugs } 10 \% \text {. Respiratory drugs } 9 \% . \\
\text { Neurological drugs } 8 \% \text {. Dermatological } 7 \% \text { and } \\
\text { gastrointestinal } 7 \% .\end{array}$ & $\begin{array}{l}\text { Oral medications (capsules or tablets) } \\
\text { were most commonly returned ( } 64 \%) \text {, } \\
\text { followed by liquid }(12 \%) \text {, creams } \\
(11 \%) \text {, inhalers }(7 \%) \text {, or miscellaneous } \\
\text { (6\%; e.g., eye glasses, hearing aid } \\
\text { batteries, medical equipment). } \\
\text { Approximately } 17,000 \text { oral pills were } \\
\text { collected during the study period. }\end{array}$ & $\begin{array}{l}\text { Unable to describe } \\
\text { respondent demographic } \\
\text { information. }\end{array}$ \\
\hline 2016 & Maeng et al. [34] & $\begin{array}{l}\text { U.S.A.; Regional health } \\
\text { plan in Central } \\
\text { Pennsylvania }\end{array}$ & $\begin{array}{l}\text { The predominant therapeutic group was pain medication } \\
(15 \%) \text {, hypertension }(14 \%) \text {, antibiotics }(11 \%) \text {, and } \\
\text { psychiatric disorders }(9 \%) .\end{array}$ & Not studied. & $\begin{array}{l}\text { Unable to describe } \\
\text { respondent demographic } \\
\text { information. }\end{array}$ \\
\hline
\end{tabular}


Table A2. Cont.

\begin{tabular}{|c|c|c|c|c|c|}
\hline Year of Study & Author(s) & Settings/Country & Therapeutic Category of the Unused, Wasted Medicine & Dosage Form & Study Limitation \\
\hline 2014 & Vogler et al. [66] & Austria; Vienna & 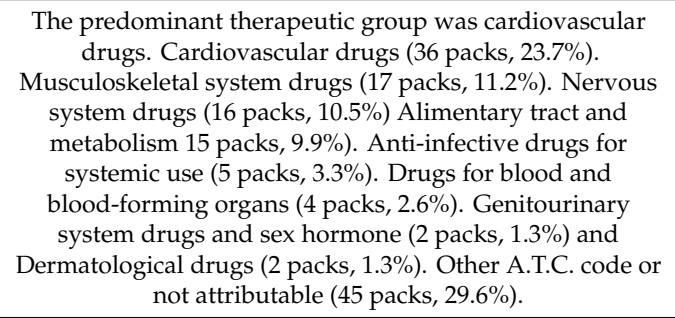 & $\begin{array}{l}\text { Oral medications were the most } \\
\text { commonly founded } 86.8 \% \text { (usually } \\
\text { solid oral), followed by dermal } 6.7 \% \text {, } \\
\text { parental } 4 \% \text {, nasal } 0.7 \% \text {, pulmonary } \\
0.7 \% \text {, eye } 0.7 \% \text {, and dental } 0.7 \% \text {. }\end{array}$ & $\begin{array}{l}\text { Unable to describe } \\
\text { respondent demographic } \\
\text { information. }\end{array}$ \\
\hline 2013 & Chien et al. [71] & $\begin{array}{c}\text { Taiwan; Shuang-Ho } \\
\text { university teaching } \\
\text { hospital }\end{array}$ & $\begin{array}{l}\text { Among the discarded medications, gastrointestinal drugs } \\
\text { were at the top of the list of all discarded medications. The } \\
\text { analysis of discarded and unused drugs revealed that } \\
\text { Strocain (oxethazaine, polymigel) was on top of the list, } \\
\text { followed by Glucobay (acarbose), Mopride (mosapride), } \\
\text { and Loditon (metformin). Gastrointestinal drugs: } 25.93 \% \text {. } \\
\text { Cardiovascular drugs: } 22.49 \% \text {. Anti-inflammatory drugs: } \\
\text { 12.15\%. Anti-diabetic drugs: } 9.49 \% \text {. Cold medicines: } 6.83 \% \text {. } \\
\text { Psychiatric drugs: } 5.44 \% \text {. Respiratory drugs: } 2.16 \% \text {. } \\
\text { Rheumatological drugs: } 1.52 \% \text {. Antimicrobial drugs: } 1.42 \% \text {. } \\
\text { Others: } 9.19 \% \text {. Health foods: } 3.38 \% \text {. }\end{array}$ & Tablets, bottles, and tubes. & $\begin{array}{l}\text { Unable to describe } \\
\text { respondent demographic } \\
\text { information. }\end{array}$ \\
\hline 2013 & Abushanab et al. [48] & Jordan; Amman & $\begin{array}{l}\text { Alimentary tract and metabolism drugs were the most } \\
\text { commonly found in household (both used and unused). } \\
\text { Stored drug products were classified by A.T.C. code of } \\
\text { WHO. Alimentary tract and metabolism: } 519 \text { ( } 20.7 \%) \text {. } \\
\text { Nervous system: } 370(17.3 \%) \text {. Musculoskeletal system: } 313 \\
(12.9 \%) \text {. Respiratory system: } 291(12 \%) \text {. Cardiovascular } \\
\text { system: } 256(10.9 \%) \text {. Anti-infective for systemic use: } 252 \\
(10.6 \%) \text {. Dermatological: } 149 \text { (5.4\%). Blood and } \\
\text { blood-forming organs: } 109(4.6 \%) \text {. Genitourinary system } \\
\text { and sex hormones: } 31(1.1 \%) \text {. Systemic hormonal } \\
\text { preparations, excl. sex hormones and insulin: } 18(1.1 \%) \text {. } \\
\text { Anti-parasitic products, insecticides and repellents: } 13 \\
(0.7 \%) \text {. Anti-neoplastic and immune-modulating agents } 8 \\
(0.3 \%) \text {, sensory organs } 63(2.5 \%) .\end{array}$ & Not studied. & $\begin{array}{l}\text { Studied the medication } \\
\text { stored at home the } \\
\text { estimated the unused } \\
\text { wasted medicine as the } \\
\text { sum of drug products that } \\
\text { had expired, had no clear } \\
\text { expiration date, or which } \\
\text { had never been used since } \\
\text { dispensing. So not } \\
\text { directly investigate the } \\
\text { unused wasted medicine. }\end{array}$ \\
\hline
\end{tabular}


Table A2. Cont.

\begin{tabular}{|c|c|c|c|c|c|}
\hline Year of Study & Author(s) & Settings/Country & Therapeutic Category of the Unused, Wasted Medicine & Dosage Form & Study Limitation \\
\hline 2012 & Al-Azzam et al. [47] & $\begin{array}{l}\text { Jordan; North of Jordan } \\
\text { particularly Irbid }\end{array}$ & 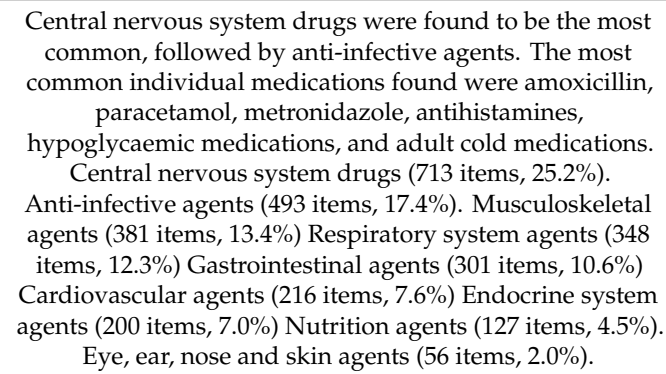 & $\begin{array}{c}\text { Tablets (1794 items, } 63.3 \%) \\
\text { Capsules (332 items, } 11.7 \%) \\
\text { Syrups ( } 250 \text { items, } 8.8 \%) \\
\text { Suspensions }(201,7.1 \%) \\
\text { Suppositories (117 items, } 4.1 \%) \\
\text { Creams/ointments/gels (43 items, } \\
1.5 \%) \\
\text { All forms of injections ( } 53 \text { items, } 1.9 \% \text { ) } \\
\text { Drops/nasal or oral puff (45 items, } \\
1.6 \%) .\end{array}$ & $\begin{array}{l}\text { A sample was selected } \\
\text { from northern Jordan, } \\
\text { which may not } \\
\text { representative of the } \\
\text { whole of Jordan. }\end{array}$ \\
\hline 2002 & Abou-Auda [27] & $\begin{array}{c}5 \text { regions in Saudi Arabia } \\
\text { and other Gulf countries } \\
\text { (Kuwait, U.A.E., Qatar, } \\
\text { and Oman) }\end{array}$ & 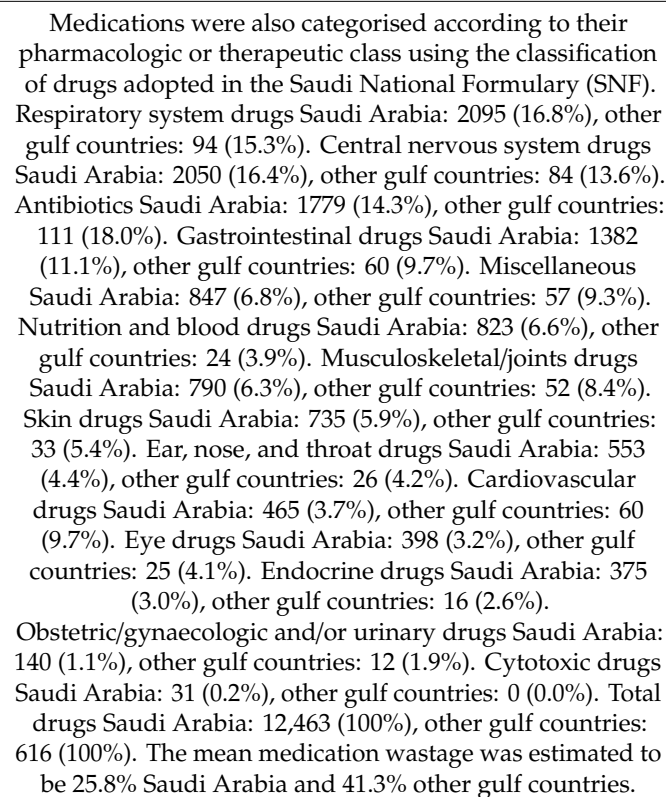 & Not studied. & $\begin{array}{l}\text { Unable to describe } \\
\text { respondent demographic } \\
\text { information. }\end{array}$ \\
\hline
\end{tabular}


Table A2. Cont.

\begin{tabular}{|c|c|c|c|c|c|}
\hline Year of Study & Author(s) & Settings/Country & Therapeutic Category of the Unused, Wasted Medicine & Dosage Form & Study Limitation \\
\hline 2011 & Kheir et al. [51] & Qatar & $\begin{array}{l}\text { The majority of the drugs stored }(n=58 ; 21 \%) \text { in the } \\
\text { participating homes were analgesics. Nonsteroidal } \\
\text { anti-inflammatory drugs were the second most commonly } \\
\text { stored drugs, representing } 16 \% \text { of all the drugs. }\end{array}$ & Not reported. & $\begin{array}{l}\text { There was potential for } \\
\text { selection and social } \\
\text { desirability bias as a result } \\
\text { of the strategy of using } \\
\text { the telephone to conduct } \\
\text { an interview. In addition, } \\
\text { interviews were } \\
\text { conducted during } \\
\text { working hours, which } \\
\text { could run the risk of } \\
\text { excluding highly } \\
\text { educated young subjects. } \\
\text { Due to the small sample } \\
\text { size, the results of this } \\
\text { exploratory study should } \\
\text { be considered with } \\
\text { caution. }\end{array}$ \\
\hline 2007 & Al-Siyabi et al. [60] & $\begin{array}{c}\text { Oman; Sultan Qaboos } \\
\text { University Hospital } \\
\text { (SQUH) }\end{array}$ & $\begin{array}{c}\text { Cardiovascular drugs were the most common } \\
\text { pharmacological group of returned drugs. The drugs were } \\
\text { classified according to the classification index of the British } \\
\text { National Formulary. Cardiovascular drugs: } 24 \% \text {. Central } \\
\text { nervous system drugs: } 14 \% \text {. Anti-infective drugs: } 13 \% \text {. } \\
\text { Endocrine drugs: } 10 \% \text {. Nutrition: } 9 \% \text {. Gastrointestinal } \\
\text { drugs: } 8 \% \text {, and Musculoskeletal system drugs: } 8 \% \text {. } \\
\text { Respiratory system drugs: } 5 \% \text {. Immunosuppressant drugs: } \\
\text { 3\%. Eye/Ear drugs: } 2 \% \text {. }\end{array}$ & Not studied. & $\begin{array}{l}\text { Unable to describe } \\
\text { respondent demographic } \\
\text { information. } \\
\text { As it included only } \\
\text { medicines with SQUH } \\
\text { labels, others were missed, } \\
\text { and this may } \\
\text { underestimate the extent } \\
\text { of unused medicines. }\end{array}$ \\
\hline 2004 & Wongpoowarak et al. [20] & Thailand; Songkhla & 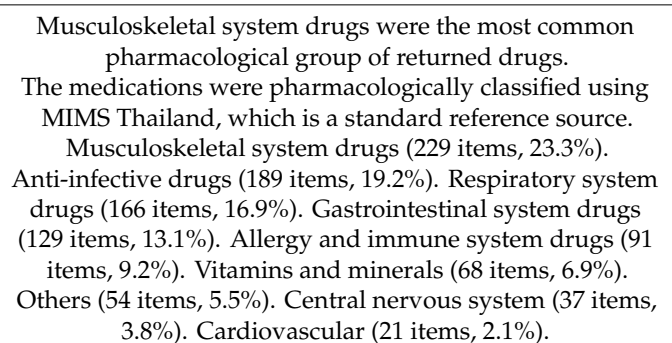 & $\begin{array}{c}\text { Oral dosage forms compromised } \\
95.6 \%(951 \text { items). } \\
\text { Oral tablets or capsules }(636 \text { items, } \\
63.9 \%) . \\
\text { Oral liquids }(311 \text { items, } 31.3 \%) \\
\text { Eye drops }(23 \text { items, } 2.3 \%) \\
\text { Topical liquids }(14 \text { items, } 1.4 \%) \\
\text { Creams }(5 \text { items, } 0.5 \%) . \\
\text { Oral powders }(4 \text { items, } 0.4 \%) \\
\text { Inhalers ( } 2 \text { items, } 0.2 \%)\end{array}$ & $\begin{array}{l}\text { This study was a snapshot } \\
\text { study, as the studied } \\
\text { population was one of } 14 \\
\text { provinces in southern } \\
\text { Thailand. }\end{array}$ \\
\hline
\end{tabular}


Table A2. Cont.

\begin{tabular}{|c|c|c|c|c|c|}
\hline Year of Study & Author(s) & Settings/Country & Therapeutic Category of the Unused, Wasted Medicine & Dosage Form & Study Limitation \\
\hline 2013 & Sooksriwong et al. [50] & $\begin{array}{l}\text { Thailand; } 4 \text { regions of } \\
\text { Thailand: Bangkok, } \\
\text { Chiang Mai, } \\
\text { Khon Kaen, } \\
\text { Mahasarakham and } \\
\text { Songkla }\end{array}$ & $\begin{array}{l}\text { A total of } 2208 \text { drug items found in household surveys were } \\
\text { classified into } 5 \text { groups of the mostly found drugs. These } \\
\text { were } 343 \text { non-opioid analgesics and antipyretic drugs, } 188 \\
\text { antacids, anti-reflux agents and anti-ulcer, } 180 \text { nonsteroidal } \\
\text { anti-inflammatory drugs (NSAIDs), } 127 \text { antihistamine and } \\
\text { anti-allergic and } 119 \text { anti-diabetic drugs. Top } 5 \text { of the most } \\
\text { found rarely or unused drugs, classified as leftover } \\
\text { medicines, were NSAIDs ( } 49 \text { items), penicillin ( } 38 \text { items), } \\
\text { G.I.T. regulators, and antiflatulents ( } 36 \text { items). } \\
\text { Of the total of } 2208 \text { drug items found in household, } 82 \text { items } \\
\text { (3.7\%) and } 45 \text { items ( } 2.0 \% \text { ) of drugs were already expired } \\
\text { and deteriorated, respectively. }\end{array}$ & Not studied. & $\begin{array}{l}\text { Unable to describe } \\
\text { respondent demographic } \\
\text { information. }\end{array}$ \\
\hline 2011 & El-Hamamsy A [26] & Egypt; Cairo & $\begin{array}{l}\text { The returned medications were classified according to the } \\
\text { British National Formulary (BNF). Antibiotics were the } \\
\text { most common pharmacological group of returned } \\
\text { medications. Antibiotics (109 items, } 20.15 \%) \text {. } \\
\text { Gastrointestinal system drugs }(88 \text { items, } 16.27 \%) \text {. } \\
\text { Cardiovascular system drugs }(58 \text { items, } 10.72 \%) \text {. } \\
\text { Respiratory system drugs ( } 44 \text { items, } 8.13 \% \text { ). Nervous } \\
\text { system drugs ( }(39 \text { items, } 7.20 \%) \text {. Analgesics and } \\
\text { anti-inflammatory ( } 38 \text { items, } 7.02 \%) \text {. Dermatological drugs } \\
\text { (35 items, } 6.47 \% \text { ). Blood and blood-forming organs ( } 29 \\
\text { items, } 5.36 \%) \text {. Systemic hormonal preparations, sex } \\
\text { hormones, and insulin's }(27 \text { items, } 4.99 \%) \text {. Anti-parasitic } \\
\text { products, insecticides, and repellents ( } 25 \text { items, } 4.62 \%) \text {. } \\
\text { Genitourinary system ( }(20 \text { items, } 3.69 \% \text { ). Antineoplastic and } \\
\text { immune-modulating agents }(3 \text { items, } 0.55 \%) \text {. Various others } \\
\text { (26 items, } 4.80 \%) \text {. }\end{array}$ & Not studied. & $\begin{array}{l}\text { Unable to describe } \\
\text { respondent demographic } \\
\text { information. }\end{array}$ \\
\hline 2012 & Ibrahim et al. [49] & Egypt; Alexandria & 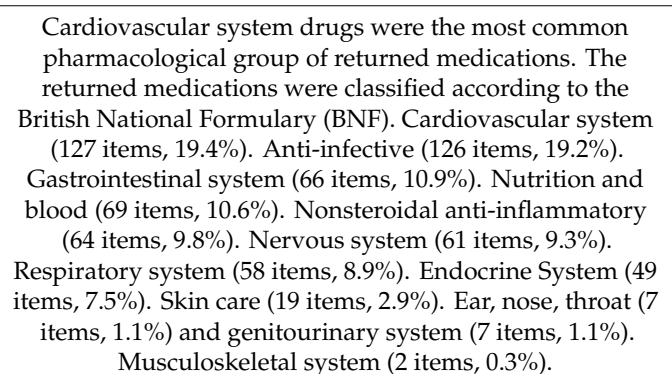 & Not studied. & $\begin{array}{l}\text { This study did not } \\
\text { estimate the quantities of } \\
\text { unused medicines in } \\
\text { patient's home. As result, } \\
\text { it is likely that it may } \\
\text { underestimate the extent } \\
\text { of unused medicines in } \\
\text { the community. }\end{array}$ \\
\hline
\end{tabular}


Table A2. Cont.

\begin{tabular}{|c|c|c|c|c|c|}
\hline Year of Study & Author(s) & Settings/Country & Therapeutic Category of the Unused, Wasted Medicine & Dosage Form & Study Limitation \\
\hline 2010 & Guirguis et al. [32] & $\begin{array}{l}\text { Australia; St Vincent's } \\
\text { Hospital, Melbourne }\end{array}$ & $\begin{array}{l}\text { Cardiovascular system drugs were the most common } \\
\text { pharmacological group of returned medications. The } \\
\text { smallest group was that of topicals, e.g., creams and } \\
\text { ointments. } \\
\text { Cardiovascular system drugs ( } 78 \text { items, } 26.6 \%) \text {. } \\
\text { Analgesics/anti-inflammatories ( } 62 \text { items, } 21.2 \%) \text {. } \\
\text { Neuropsychiatry drugs }(8.5 \%) \text {. Respiratory system drugs } \\
(8 \%) \text {. Eye/Ear/Nose drugs }(7.5 \%) \text {. Gastrointestinal drugs } \\
(7 \%) \text {, and Antimicrobials }(7 \%) \text {. Herbals and vitamins }(12 \\
\text { items, } 4.1 \%) \text {. Diabetes drugs ( }(3 \%) \text {. Topicals, e.g., creams } \\
\text { and ointments ( }(8 \text { items, } 2.7 \%) \text {. Miscellaneous }(4.5 \%) \text {. }\end{array}$ & $\begin{array}{l}\text { They report that they collect topicals } \\
\text { cream, ointment along with other } \\
\text { dosage forms (that was not defined). }\end{array}$ & $\begin{array}{l}\text { Sample size and the } \\
\text { number of returns are } \\
\text { small, which make it } \\
\text { difficult to extrapolate the } \\
\text { result to the whole of } \\
\text { Australia. }\end{array}$ \\
\hline 2014 & Kagashe et al. [57] & $\begin{array}{l}\text { Tanzania; tertiary hospital } \\
\text { in Dar es Salaam city }\end{array}$ & $\begin{array}{c}\text { Medicines wasted in this study were categorised into three } \\
\text { major groups, anti-infective, cardiovascular medications, } \\
\text { and others. Anti-infective drugs: } 18.9 \% \text {. Cardiovascular } \\
\text { drugs: } 8.9 \% \text {. Other drugs: } 23.7 \% \text {. }\end{array}$ & $\begin{array}{l}\text { Oral solids drugs were the most } \\
\text { common wasted dosage form } 40.6 \% \\
\text { followed by injections } 9.2 \% \text {, with } \\
\text { very few topicals preparations. }\end{array}$ & $\begin{array}{c}\text { Since only } \\
\text { hospital-prescribed } \\
\text { medicines was included, } \\
\text { others may be missed, } \\
\text { which may underestimate } \\
\text { the extent of unused } \\
\text { medicines. }\end{array}$ \\
\hline 2007 & Abahussain et al. [33] & Kuwait; Kuwait city & $\begin{array}{l}\text { No medicines were collected from the } 200 \text { households } \\
\text { participating in the municipal collection program The } \\
\text { second intervention yielded } 123 \text { medicines from } 14 \text { homes; } \\
\text { the most common class of unwanted medicines were drugs } \\
\text { for respiratory system. Unwanted medications were } \\
\text { classified according to the ATC WHO classification. } \\
\text { A third of all unwanted medicines were for the respiratory } \\
\text { system ( } 38 \% \text { of these were cough and cold preparations, } \\
25 \% \text { nasal preparations). } 12 \% \text { of the medicines were for the } \\
\text { musculoskeletal system ( } 53 \% \text { oral NSAIDs) or were } \\
\text { dermatologicals ( } 33 \% \text { topical antibiotics). }\end{array}$ & $\begin{array}{l}\text { There were } 141 \text { items (including } \\
\text { duplicates). } 508 \text { tablets/capsules, } 25 \\
\text { oral liquids, } 20 \text { tubes, } 21 \text { dropper } \\
\text { bottles, and various other dosage } \\
\text { forms. }\end{array}$ & $\begin{array}{l}\text { Sample size and the } \\
\text { number of returns are } \\
\text { small, which make it } \\
\text { difficult to extrapolate the } \\
\text { result to the whole of } \\
\text { Kuwait. } \\
\text { Unable to describe } \\
\text { respondent demographic } \\
\text { information. }\end{array}$ \\
\hline 2013 & Aditya [43] & $\begin{array}{l}\text { India; dental hospital in } \\
\text { North India }\end{array}$ & $\begin{array}{l}\text { Qualitative analysis of expired medications at home } \\
\text { revealed antipyretics ( } 54 \% \text { ), analgesics }(64 \%) \text {, followed by } \\
\text { antihistamines ( } 35 \%) \text { to be hoarded in home } \\
\text { pharmacies/medicine chests. Other drugs were antibiotics } \\
(26 \%) \text {, antacids }(23 \%) \text {, topical drugs ( } 39 \%) \text { and supplements } \\
\text { (vitamins) }(41 \%) \text {. Excessive buying of over-the counter } \\
\text { (O.T.C.) drugs (53\%); self-discontinuation }(17 \%) \text {, and } \\
\text { expiration of drugs ( } 24 \%) \text { resulted in possession of } \\
\text { unused/leftover medications at home. }\end{array}$ & Not studied. & $\begin{array}{l}\text { Small sample size from a } \\
\text { specific region in India, } \\
\text { which make it difficult to } \\
\text { generalise and extrapolate } \\
\text { the results to the whole of } \\
\text { India. }\end{array}$ \\
\hline 2011 & Gupta et al. [42] & India; Greater Noida City & $\begin{array}{l}\text { Most of the expired drugs are in the category of analgesics } \\
\text { and NSAIDs (23.93\%) followed by nutritional supplements } \\
(22.56 \%) \text {, antibiotics ( } 14.94 \%), \text { expectorants and mucolytics } \\
(6.77 \%) \text {, bronchodilators }(5.31 \%) \text {, and antacids }(6.53 \%) \text {. }\end{array}$ & $\begin{array}{l}\text { Oral tablets were the most common; } \\
\text { other dosage forms include syrups, } \\
\text { capsules, suspensions, powders, eye } \\
\text { drops, gels, churna, cream, and ear } \\
\text { wax softener. }\end{array}$ & $\begin{array}{l}\text { Defined medicine wastes } \\
\text { as only expired medicines, } \\
\text { which may underestimate } \\
\text { the extent of unused } \\
\text { wasted medicines. }\end{array}$ \\
\hline
\end{tabular}


Table A2. Cont.

\begin{tabular}{|c|c|c|c|c|c|}
\hline Year of Study & Author(s) & Settings/Country & Therapeutic Category of the Unused, Wasted Medicine & Dosage Form & Study Limitation \\
\hline 2014 & Mirza and Ganguly [44] & $\begin{array}{c}\text { Anand district of Gujarat, } \\
\text { India }\end{array}$ & $\begin{array}{l}\text { Among the prescribed medicines, the majority of medicines } \\
\text { were from cardiovascular disease (19.88\%) and from } \\
\text { without prescription medicines, nonsteroidal } \\
\text { anti-inflammatory drugs (NSAIDs) were the major group } \\
\text { available at houses ( } 35.13 \%) .\end{array}$ & Not reported. & $\begin{array}{l}\text { Since the interviewers } \\
\text { were fully aware of the } \\
\text { purpose of the project, } \\
\text { some information } \\
\text { regarding medicines was } \\
\text { not shared, which might } \\
\text { have led to a skewed } \\
\text { result. }\end{array}$ \\
\hline 2009 & Ali et al. [24] & Malaysia; Universiti Sains & $\begin{array}{l}\text { The total number of medicines found unused was } 1724 \\
\text { drug products with vitamins and minerals as the most } \\
\text { common class of unused drugs. Vitamins and minerals: } 427 \\
(24.8 \%) \text {. Gastrointestinal drugs: } 298(17.3 \%) \text {. Analgesic and } \\
\text { antipyretics: } 293(17.0 \%) \text {. Antibiotics: } 174(10.0 \%) \text {. Ear, } \\
\text { nose, and throat drugs: } 159(9.2 \%) \text {. Respiratory drugs: } 106 \\
\text { (6.3\%). Dermatological products: } 97 \text { (5.6\%). Anti-rheumatic } \\
\text { and anti-inflammatory: } 69(4.0 \%) \text {. Others (C.N.S. drugs, } \\
\text { endocrine and metabolic drugs, cardiovascular drugs, } \\
\text { genitourinary drugs, and others): } 101 \text { (5.8\%). }\end{array}$ & $\begin{array}{l}68.5 \%(n=1181) \text { of the medications } \\
\text { were in the form of tablets and pills } \\
\text { while capsules constituted } 14.6 \%(n= \\
\text { 252) of the overall amount. } 5 \%(n= \\
87) \text { syrups and suspensions while } \\
4.9 \%(n=84) \text { were creams and } \\
\text { ointments. } \\
\text { Less than } 1.0 \%(n=5) \text { consisted of } \\
\text { inhalers, with } 0.2 \%(n=4) \\
\text { suppositories of the overall total. }\end{array}$ & $\begin{array}{l}\text { Sampling of only female } \\
\text { students made it } \\
\text { impossible to generalise } \\
\text { the results to the whole } \\
\text { student population in the } \\
\text { campus. }\end{array}$ \\
\hline 2020 & Hassali and Shakeel [45] & Selangor, Malaysia & $\begin{array}{l}\text { The major classes of medications that were purchased } \\
\text { included antibiotics (207; } 48.5 \%) \text { followed by } \\
\text { painkillers/nonsteroidal anti-inflammatory drugs (NSAIDs) } \\
\text { (101; } 23.7 \%) \text {. In addition, anti-hypertensive } 51(11.9 \%) \text {, } \\
\text { anti-diabetic } 20(4.6 \%) \text {, OTC antihistamines } 34(7.9 \%), \text { and } \\
\text { multi-vitamins and other supplements } 13(3.0 \%) \text {. }\end{array}$ & Not studied. & $\begin{array}{l}\text { The sample size of the } \\
\text { study was small to depict } \\
\text { a clear picture of the entire } \\
\text { Selangor population; } \\
\text { hence, the findings of the } \\
\text { current study are not } \\
\text { generalisable to all of } \\
\text { Malaysia. }\end{array}$ \\
\hline 2014 & Aboagye et al. [59] & Ghana & $\begin{array}{c}\text { Leftover medicines: } \\
\text { Paracetamol tablets } 27 \\
\text { Amoxicillin capsules } 12 \\
\text { Aspirin tablets } 4 \\
\text { Metronidazole tablets } 5 \\
\text { F-PAC (Paracetamol/Aspirin/Caffeine) } 3 \\
\text { Vitamin B complex tablets } 7 \\
\text { Multi-vitamins tablets } 7 \\
\text { Diclofenac tablets } 3 \\
\text { Magnesium trisilicate tablets } 3 \\
\text { Ibuprofen tablets } 5 \\
\text { Others/Unidentified } 45 \\
\text { Do not remember } 1 .\end{array}$ & Not studied. & $\begin{array}{l}\text { Sample size and the } \\
\text { number of returns are } \\
\text { small which make it } \\
\text { difficult to extrapolate the } \\
\text { result to the whole of } \\
\text { Ghana. } \\
\text { Leftover medicines were } \\
\text { described as individual } \\
\text { medicine, not as a group. }\end{array}$ \\
\hline
\end{tabular}


Table A2. Cont.

\begin{tabular}{|c|c|c|c|c|c|}
\hline Year of Study & Author(s) & Settings/Country & Therapeutic Category of the Unused, Wasted Medicine & Dosage Form & Study Limitation \\
\hline 2019 & Huang et al. [52] & $\begin{array}{l}\text { Six provinces in North, } \\
\text { Central, and Southern } \\
\text { regions of China }\end{array}$ & $\begin{array}{l}\text { Cold medication }(86.1 \%) \text { was the most common category of } \\
\text { medicines kept in households. Specifically, the following } \\
\text { were the major classes of medicines found in the } \\
\text { households: gastrointestinal medicines }(27.0 \%) \text {, pain } \\
\text { medications }(22.9 \%) \text {, vitamins }(20.6 \%) \text {, antibiotics }(19.0 \%) \text {, } \\
\text { external painkillers }(16.5 \%) \text {, and external anti-inflammatory } \\
\text { antidotes }(15.4 \%) .\end{array}$ & Not studied. & Not reported. \\
\hline 2019 & Vella and West [58] & Maltese village, Malta & $\begin{array}{l}\text { The most common class of disposed medications was that } \\
\text { pertaining to the alimentary tract }(24.6 \%) \text {, closely followed } \\
\text { by medicines belonging to the respiratory group ( } 23.8 \%) \text {. } \\
10.5 \% \text { of the unused disposed medications were from the } \\
\text { musculoskeletal group, which includes medications such as } \\
\text { nonsteroidal anti-inflammatory drugs (NSAIDs), and } \\
\text { supplements, such as glucosamine. The medications with } \\
\text { the lowest return rate were anti-neoplastic and } \\
\text { immunomodulating agents }(0.7 \%), \text { followed by } \\
\text { anti-parasitic medications }(0.2 \%) \text {. }\end{array}$ & $\begin{array}{l}\text { Solid dosage forms were counted } \\
\text { manually, liquid dosage forms were } \\
\text { measured using a calibrated } \\
\text { measuring cylinder, dermatological } \\
\text { preparations were measured using } \\
\text { kitchen weighing scales, and inhalers } \\
\text { that had a counter were recorded as } \\
\text { per value available on the counter. } \\
\text { Unused inhalers without a counter, } \\
\text { eye drops, ear drops, nasal drops, } \\
\text { and nasal and oral sprays were not } \\
\text { quantified as effective entries, as their } \\
\text { quantities could not be safely } \\
\text { determined. }\end{array}$ & $\begin{array}{l}\text { This study excluded some } \\
\text { dosage forms whilst } \\
\text { quantifying and costing } \\
\text { waste, such as eye drops, } \\
\text { inhalers, and nasal sprays. } \\
\text { Therefore, the actual cost } \\
\text { of waste presented in this } \\
\text { study is an underestimate. }\end{array}$ \\
\hline 2020 & Insani et al. [54] & Bandung, Indonesia & $\begin{array}{l}\text { NSAIDs were the most common medicines left unused ( } n= \\
\text { 372) followed by vitamins and nutritional supplements }(n= \\
\qquad 215) \text { and antibiotics }(n=171) .\end{array}$ & Not reported. & $\begin{array}{l}\text { This study was conducted } \\
\text { in one region in Bandung } \\
\text { (small sample size); thus, } \\
\text { its generalisation for the } \\
\text { Indonesian population is } \\
\text { limited. In addition, the } \\
\text { predictors associated with } \\
\text { disposal practice were not } \\
\text { identified. }\end{array}$ \\
\hline 2010 & Jassim [53] & Basrah, Iraq & $\begin{array}{l}\text { Overall, } 4279 \text { items of drugs were analysed. Antibiotics } \\
\text { were the leading household stored drugs }(26.43 \%) \text {, followed } \\
\text { by antipyretic/analgesics }(19.58 \%) \text {, and NSAIDs } \\
\text { (nonsteroidal anti-inflammatory drugs) }(11.45 \%) \text {. These } \\
\text { drugs constituted ( } 57 \% \text { ) of the total drugs stored. }\end{array}$ & Not reported. & $\begin{array}{l}\text { This study was conducted } \\
\text { in } 300 \text { households in } \\
\text { Basrah, southern Iraq (i.e., } \\
\text { one region in Iraq). Small } \\
\text { sample size. }\end{array}$ \\
\hline
\end{tabular}


Table A2. Cont.

\begin{tabular}{|c|c|c|c|c|c|}
\hline Year of Study & Author(s) & Settings/Country & Therapeutic Category of the Unused, Wasted Medicine & Dosage Form & Study Limitation \\
\hline 2012 & Auta et al. [55] & Nigeria & $\begin{array}{l}\text { Common classes of medicines reported as leftover } \\
\text { medicines were analgesics }(36.4 \%) \text {, antibiotics }(33.1 \%) \text {, and } \\
\text { antihistamines }(11.9 \%) .\end{array}$ & $\begin{array}{l}\text { Respondents reported having about } \\
318 \text { medicines items (representing } \\
2.56 \text { items per student's room) in all, } \\
\text { with the tablets ( } 62.3 \%) \text { being the } \\
\text { most common dosage form. } \\
\text { Followed by capsules }(16.4 \%), \\
\text { lotions/creams }(11.6 \%) \text {, and } \\
\text { syrups/suspensions }(6.3 \%) .\end{array}$ & $\begin{array}{l}\text { This study was based on } \\
\text { the self-reported presence } \\
\text { of medicines in } \\
\text { respondents' residence. } \\
\text { Therefore, it is possible } \\
\text { that the medicines were } \\
\text { under-reported or some } \\
\text { names of unidentified } \\
\text { medicines were wrongly } \\
\text { reported. In addition, the } \\
\text { sample size was small. }\end{array}$ \\
\hline 2015 & Wondimu et al. [41] & $\begin{array}{c}\text { Tigray Region, Northern } \\
\text { Ethiopia }\end{array}$ & $\begin{array}{l}\text { The most common classes of drugs found in the households } \\
\text { were analgesics ( } 29 \%) \text { and antibiotics ( } 25 \%) \text {. Generally, } \\
\text { more than half }(62 \%) \text { of the medications were used for } \\
\text { ongoing treatment. }\end{array}$ & $\begin{array}{l}\text { Most }(70 \%) \text { of the medicines were } \\
\text { available in the form of tablets, } \\
\text { followed by capsules }(13.2 \%) \text {, oral } \\
\text { liquid }(9.9 \%) \text {, semisolids }(2.8 \%) \text {, } \\
\text { injections (1.8\%), and other dosage } \\
\text { forms }(2.2 \%) \text {. }\end{array}$ & $\begin{array}{l}\text { One of the study } \\
\text { limitations was the } \\
\text { cross-sectional design } \\
\text { employed, which might } \\
\text { be affected by temporal } \\
\text { relationship establishment } \\
\text { with some variables and } \\
\text { could not provide much } \\
\text { more substantial evidence } \\
\text { of causality, unlike a } \\
\text { longitudinal design. }\end{array}$ \\
\hline 2017 & Teni et al. [36] & $\begin{array}{l}\text { Gondar town, } \\
\text { northwestern Ethiopia }\end{array}$ & $\begin{array}{l}\text { Anti-infectives for systemic use }(23.9 \%) \text {, medicines for } \\
\text { alimentary tract and metabolism }(19.2 \%) \text { and those for the } \\
\text { cardiovascular system }(17.7 \%) \text { ranked top. }\end{array}$ & $\begin{array}{l}\text { Of the total } 553 \text { medicines stored, } \\
\text { more than three quarters }(80.8 \%) \\
\text { were of solid dosage forms. Liquid } \\
\text { dosage forms were }(16.6 \%) \text { and } \\
\text { semisolids were }(2.5 \%) \text {. }\end{array}$ & $\begin{array}{l}\text { The study did not include } \\
\text { the rural parts of Gondar } \\
\text { Town. The small sample } \\
\text { size makes the findings } \\
\text { not representative of the } \\
\text { pattern of household } \\
\text { medicine storage practice } \\
\text { in those areas. }\end{array}$ \\
\hline 2019 & Ebrahim et al. [37] & $\begin{array}{l}\text { Awi zone, Amhara } \\
\text { regional state, Ethiopia }\end{array}$ & $\begin{array}{l}\text { Anti-infective medications were found to be the most } \\
\text { frequently unused medications } 63(36.4 \%) \text { followed by } \\
\text { antipain medications } 37(21.4 \%) \text { and cardiovascular } \\
\text { medications } 19(11 \%) \text {. }\end{array}$ & Not reported. & $\begin{array}{l}\text { Health centres and private } \\
\text { health facilities were not } \\
\text { included in the study, and } \\
\text { thus, the results may have } \\
\text { been slightly different if } \\
\text { those facilities were } \\
\text { included. }\end{array}$ \\
\hline
\end{tabular}


Table A2. Cont.

\begin{tabular}{|c|c|c|c|c|c|}
\hline Year of Study & Author(s) & Settings/Country & Therapeutic Category of the Unused, Wasted Medicine & Dosage Form & Study Limitation \\
\hline 2020 & Gudeta and Assefa [39] & Jimma city, Ethiopia & $\begin{array}{l}\text { Antibiotics, } 31(35.6 \%) \text {, and anti-hypertensive, } 21(24.1 \%) \\
\text { constituted the highest proportion of the waste. }\end{array}$ & Not reported. & $\begin{array}{l}\text { The sample size was } \\
\text { small. In addition, the } \\
\text { current study was } \\
\text { conducted among private } \\
\text { practitioners. Thus, } \\
\text { prospective researchers } \\
\text { may consider both private } \\
\text { and public professionals } \\
\text { for their comparative } \\
\text { study. }\end{array}$ \\
\hline 2020 & Kahsay et al. [40] & Adigrat city, Ethiopia & $\begin{array}{l}\text { The common types of medicines kept in households were } \\
\text { analgesics }(41.5 \%) \text { and antibiotics ( } 36.7 \%) \text {. In addition, } \\
\text { antipain and antibiotic }(4.8 \%) \text {, anti-diabetic }(5.3 \%) \text {, and } \\
\text { anti-hypertensive }(8 \%) \text { medicines were other types of } \\
\text { unused medications found in homes. }\end{array}$ & Not reported. & $\begin{array}{l}\text { The small sample size and } \\
\text { the cross-sectional nature } \\
\text { of the study design } \\
\text { prevent us from drawing } \\
\text { causal inferences about } \\
\text { the relationship between } \\
\text { the chosen covariates and } \\
\text { outcome variables over a } \\
\text { period. }\end{array}$ \\
\hline 2020 & Yimenu et al. [38] & $\begin{array}{l}\text { Awi zone, Amhara } \\
\text { regional state, } \\
\text { northwestern Ethiopia }\end{array}$ & $\begin{array}{l}\text { Anti-infective medicines were found to be the most } \\
\text { common unused medicines, } 53(58.9 \%) \text {, followed by } \\
\text { antipain medicines, } 16(17.8 \%) \text {. }\end{array}$ & Not reported. & $\begin{array}{l}\text { The small sample size and } \\
\text { not including the health } \\
\text { centres and private health } \\
\text { facilities were limitations } \\
\text { to this study. Thus, the } \\
\text { results may be slightly } \\
\text { different if those facilities } \\
\text { were included. }\end{array}$ \\
\hline
\end{tabular}




\section{References}

1. Pharmaceutical Waste Reduction in the NHS. 2015. Available online: https://www.england.nhs.uk/wp-content/ uploads/2015/06/pharmaceutical-waste-reduction.pdf (accessed on 30 November 2020).

2. Definition and characterization of health-care waste. In Safe Management of Wastes from Health-Care Activities, 2nd ed.; WHO: Geneva, Switzerland, 2014.

3. Opar, A. Rising drug costs prompt new uses for old pills. Nat. Med. 2006, 12, 1333. [CrossRef] [PubMed]

4. Toh, M.R.; Chew, L. Turning waste medicines to cost savings: A pilot study on the feasibility of medication recycling as a solution to drug wastage. Palliat. Med. 2016, 31, 35-41. [CrossRef] [PubMed]

5. Bekker, C.L.; Gardarsdottir, H.; Egberts, T.C.; Molenaar, H.A.; Bouvy, M.L.; Bemt, B.V.D.; Hövels, A.M. What does it cost to redispense unused medications in the pharmacy? A micro-costing study. BMC Health Serv. Res. 2019, 19, 243. [CrossRef] [PubMed]

6. Trueman, P.; Lowson, K.; Blighe, A.; Meszaros, A. Evaluation of the Scale, Causes and Costs of Waste Medicines Evaluation of the Scale, Causes and Costs of Waste Medicines. Available online: https://discovery. ucl.ac.uk/id/eprint/1350234/ (accessed on 30 November 2020).

7. Kümmerer, K. The presence of pharmaceuticals in the environment due to human use-Present knowledge and future challenges. J. Environ. Manag. 2009, 90, 2354-2366. Available online: https://pubmed.ncbi.nlm. nih.gov/19261375/ (accessed on 14 November 2020). [CrossRef] [PubMed]

8. Bound, J.P.; Voulvoulis, N. Household Disposal of Pharmaceuticals as a Pathway for Aquatic Contamination in the United Kingdom. Environ. Health Perspect. 2005, 113, 1705-1711. [CrossRef]

9. Radhakrishna, L.; Nagarajan, P.; Vijayanandhan, S.S.; Ponniah, T. Knowledge, attitude and practice (kap) towards disposal of medicines: A qualitative study among health care professionals in south India. World J. Pharm. Res. 2014, 3, 1955-1963.

10. Schwartz, T.; Kohnen, W.; Jansen, B.; Obst, U. Detection of antibiotic-resistant bacteria and their resistance genes in wastewater, surface water, and drinking water biofilms. FEMS Microbiol. Ecol. 2006, 43, 325-335. [CrossRef]

11. Länge, R.; Hutchinson, T.H.; Croudace, C.P.; Siegmund, F.; Schweinfurth, H.; Hampe, P.; Panter, G.H.; Sumpter, J.P. Effects of the synthetic estrogen $17 \alpha$-ethinylestradiol on the life-cycle of the fathead minnow (Pimephales promelas). Environ. Toxicol. Chem. 2001, 20, 1216-1227. [CrossRef]

12. Wu, P.E.; Juurlink, D.N. Unused prescription drugs should not be treated like leftovers. CMAJ 2014, 186, 815-816. [CrossRef]

13. Medicines Non-Use in Primary Care-Aston Research Explorer. Available online: https://research.aston.ac. uk/en/studentTheses/medicines-non-use-in-primary-care (accessed on 15 November 2020).

14. West, L.M.; Diack, L.; Cordina, M.; Stewart, D. A systematic review of the literature on 'medication wastage': An exploration of causative factors and effect of interventions. Int. J. Clin. Pharm. 2014, 36, 873-881. [CrossRef]

15. Waste Management Plan for England. 2013. Available online: www.gov.uk/defra (accessed on 15 November 2020).

16. McRae, D.; Allman, M.; James, D. The redistribution of medicines: Could it become a reality? Int. J. Pharm. Pr. 2016, 24, 411-418. [CrossRef] [PubMed]

17. Bekker, C.L.; Gardarsdóttir, H.; Egberts, T.C.; Bouvy, M.L.; Bemt, B.J.F.V.D. Redispensing of medicines unused by patients: A qualitative study among stakeholders. Int. J. Clin. Pharm. 2017, 39, 196-204. [CrossRef] [PubMed]

18. Alhamad, H.; Patel, N.; Donyai, P. How do people conceptualise the reuse of medicines? An interview study. Int. J. Pharm. Pr. 2018, 26, 232-241. [CrossRef] [PubMed]

19. Bekker, C.L.; Bemt, B.V.D.; Egberts, T.C.; Bouvy, M.; Gardarsdottir, H. Willingness of patients to use unused medication returned to the pharmacy by another patient: A cross-sectional survey. BMJ Open 2019, 9, e024767. [CrossRef] [PubMed]

20. Wongpoowarak, P.; Wanakamanee, U.; Panpongtham, K.; Trisdikoon, P.; Wongpoowarak, W.; Ngorsuraches, S. Unused medications at home--Reasons and costs. Int. J. Pharm. Pr. 2004, 12, 141-148. [CrossRef]

21. Braund, R.; Chuah, F.; Gilbert, R.; Gn, G.; Soh, A.; Tan, L.Y.; Yuen, Y.-C. Identification of the reasons for medication returns. NZFP 2008, 35, 248-252.

22. Makki, M.; Hassali, M.A.; Awaisu, A.; Hashmi, F.K. The Prevalence of Unused Medications in Homes. Pharmacy 2019, 7, 61. [CrossRef] [PubMed] 
23. Bekker, C.L.; Bemt, B.J.F.V.D.; Egberts, A.C.G.; Bouvy, M.L.; Gardarsdottir, H. Patient and medication factors associated with preventable medication waste and possibilities for redispensing. Int. J. Clin. Pharm. 2018, 40, 704-711. [CrossRef] [PubMed]

24. Ali, S.; Ibrahim, M. Extent of Medication Wastage and Cost among Female Students in a University Setting. Mahidol Univ. J. Pharm. Sci. 2009, 36, 34-43.

25. Garey, K.W.; Johle, M.L.; Behrman, K.; Neuhauser, M.M. Economic Consequences of Unused Medications in Houston, Texas. Ann. Pharmacother. 2004, 38, 1165-1168. [CrossRef] [PubMed]

26. El-Hamamsy, M.; Manal El-Hamamsy, A. Unused medications: How cost and how disposal of in Cairo, Egypt. Int. J. Pharm. Stud. Res. 2011, 2, 21-27.

27. Abou-Auda, H.S. An economic assessment of the extent of medication use and wastage among families in Saudi Arabia and Arabian Gulf countries. Clin. Ther. 2003, 25, 1276-1292. [CrossRef]

28. Jafarzadeh, A.; Mahboub-Ahari, A.; Naja, M.; Youse, M. Medicine Storage, Wastage and Associated Determinants among Urban Households: A Systematic Review of Household Surveys. Available online: https://doi.org/10.21203/rs.3.rs-71586/v1 (accessed on 18 November 2020).

29. DUMP - Bewell.org.nz-Nelson Bays Primary Health. Available online: https://www.yumpu.com/en/ document/view/18584754/dump-bewellorgnz-nelson-bays-primary-health (accessed on 15 November 2020).

30. Tong, A.Y.C.; Peake, B.M.; Braund, R. Disposal practices for unused medications around the world. Environ. Int. 2011, 37, 292-298. [CrossRef] [PubMed]

31. Braund, R.; Peake, B.M.; Shieffelbien, L. Disposal practices for unused medications in New Zealand. Environ. Int. 2009, 35, 952-955. [CrossRef]

32. Guirguis, K. Medications collected for disposal by outreach pharmacists in Australia. Pharm. World Sci. 2009, 32, 52-58. [CrossRef]

33. Abahussain, E.A.; Ball, D.E.; Matowe, W.C. Practice and Opinion towards Disposal of Unused Medication in Kuwait. Med. Princ. Pr. 2006, 15, 352-357. [CrossRef]

34. Maeng, D.D.; Snyder, R.C.; Medico, C.J.; Mold, W.M.; Maneval, J.E. Unused medications and disposal patterns at home: Findings from a Medicare patient survey and claims data. J. Am. Pharm. Assoc. 2016, 56, 41-46.e6. [CrossRef]

35. Moher, D.; Liberati, A.; Tetzlaff, J.; Altman, D.G. Preferred reporting items for systematic reviews and meta-analyses: The PRISMA statement. PLoS Med. 2009, 6, e1000097. [CrossRef]

36. Teni, F.S.; Surur, A.S.; Asrie, A.B.; Wondimsigegn, D.; Gelayee, D.A.; Shewamene, Z.; Legesse, B.; Birru, E.M. A household survey of medicine storage practices in Gondar town, northwestern Ethiopia. BMC Public Heal. 2017, 17, 238. [CrossRef]

37. Ebrahim, A.J.; Teni, F.S.; Yimenu, D.K. Unused and Expired Medications: Are They a Threat? A Facility-Based Cross-Sectional Study. J. Prim. Care Community Health 2019, 10. [CrossRef]

38. Yimenu, D.K.; Teni, F.S.; Ebrahim, A.J. Prevalence and Predictors of Storage of Unused Medicines among Households in Northwestern Ethiopia. J. Environ. Public Health 2020, 2020, 8703208-10. [CrossRef] [PubMed]

39. Gudeta, T.; Assefa, D. Assessment of Pharmaceuticals Waste Practices Among Private Drug Retail Outlets in Ethiopia. J. Prim. Care Community Health 2020, 11. [CrossRef] [PubMed]

40. Kahsay, H.; Ahmedin, M.; Kebede, B.; Gebrezihar, K.; Araaya, H.; Tesfay, D. Assessment of Knowledge, Attitude, and Disposal Practice of Unused and Expired Pharmaceuticals in Community of Adigrat City, Northern Ethiopia. J. Environ. Public Health 2020, 2020, 1-11. [CrossRef] [PubMed]

41. Wondimu, A.; Molla, F.; Demeke, B.; Eticha, T.; Assen, A.; Abrha, S.; Melkam, W. Household storage of medicines and associated factors in Tigray Region, Northern Ethiopia. PLoS ONE 2015, 10, e0135650. [CrossRef]

42. Gupta, J.; Alam, N.; Bhardwaj, A.; Amin, F.; Alam, M.N. Prospective survey study on assessment and education of home medicine cabinet in general population of community. IJPSR 2011, 2, 1237-1243.

43. Aditya, S. Safe medication disposal: Need to sensitize undergraduate students. Int. J. Pharm. Life Sci. 2013, 4, 2476-2480.

44. Mirza, N.; Ganguly, B. Utilization of Medicines Available at Home by General Population of Rural and Urban Set Up of Western India. J. Clin. Diagn. Res. 2016, 10, FC05-FC09. [CrossRef]

45. Hassali, M.A.; Shakeel, S. Unused and Expired Medications Disposal Practices among the General Public in Selangor, Malaysia. Pharmacy 2020, 8, 196. [CrossRef] 
46. Law, A.V.; Sakharkar, P.; Zargarzadeh, A.; Tai, B.W.B.; Hess, K.; Hata, M.; Mireles, R.; Ha, C.; Park, T.J. Taking stock of medication wastage: Unused medications in US households. Res. Soc. Adm. Pharm. 2015, 11, 571-578. [CrossRef]

47. Al-Azzam, S.I.; Al-Husein, B.A.; Alzoubi, F.; Masadeh, M.M.B. Self-Medication with Antibiotics in Jordanian Population. Int. J. Occup. Med. Environ. Health 2007, 20, 373-380. [CrossRef]

48. Abushanab, A.S.; Sweileh, W.M.; Wazaify, M. Storage and wastage of drug products in J ordanian households: A cross-sectional survey. Int. J. Pharm. Pract. 2013, 21, 185-191. [CrossRef] [PubMed]

49. Ibrahim, S.; Mamdouh, H.; El-Haddad, I.Z. Analysis of medications returned to community pharmacies in Alexandria, Egypt. Life Sci. J. 2012, 9, 746-751.

50. Sooksriwong, C.; Jarupas, C.; Chinawong, D.; Supakul, S.; Ploylermsang, C.; Sornlumlertwanich, K.; Janto, S. Values of leftover drugs in households: Preliminary study in 5 major Thai cities. J. Asian Assoc. Sch. Pharm. 2013, 2, 235-242.

51. Kheir, N.M.; El Hajj, M.; Kaissi, R.; Wilbur, K.; Yousif, A. An exploratory study on medications in Qatar homes. Drug Health Patient Saf. 2011, 3, 99-106. [CrossRef] [PubMed]

52. Huang, Y.; Wang, L.; Zhong, C.; Huang, S. Factors influencing the attention to home storage of medicines in China. BMC Public Health 2019, 19, 1-10. [CrossRef] [PubMed]

53. Jassim, A.-M. In-home Drug Storage and Self-medication with Antimicrobial Drugs in Basrah, Iraq. Oman Med. J. 2010, 25, 79-87. [CrossRef] [PubMed]

54. Insani, W.N.; Qonita, N.A.; Jannah, S.S.; Nuraliyah, N.M.; Supadmi, W.; Gatera, V.A.; Alfian, S.D.; Abdulah, R. Improper disposal practice of unused and expired pharmaceutical products in Indonesian households. Heliyon 2020, 6, e04551. [CrossRef]

55. Auta, A.; Banwat, S.B.; Sariem, C.N.; Shalkur, D.; Nasara, B.; Atuluku, M.O. Medicines in pharmacy students' residence and self-medication practices. J. Young Pharm. 2012, 4, 119-123. [CrossRef]

56. Coma, A.; Modamio, P.; Lastra, C.F.; Bouvy, M.L.; Mariño, E.L. Returned medicines in community pharmacies of Barcelona, Spain. Pharm. World Sci. 2007, 30, 272-277. [CrossRef]

57. Kagashe, G.A.; Makenya, F.B.; Buma, D. Medicines Wastage at a Tertiary Hospital in Dar Es Salaam Tanzania. J. Appl. Pharm. Sci. 2014, 4, 98-102.

58. Vella, V.; West, L.M. Analysis of Disposed Unused Medications at a Village Community Pharmacy. Pharmacy 2019, 7, 45. [CrossRef] [PubMed]

59. Aboagye, V.S.; Kyei, K.A. Disposal of Leftover Drugs in Ghana. Pharm. Res. 2014, 4, 84-91.

60. Al-Siyabi, K.; Al-Riyami, K. Value and Types of Medicines Returned by Patients to Sultan Qaboos University Hospital Pharmacy, Oman. Sultan Qaboos Univ. Med. J. [SQUMJ] 2007, 7, 109-115. [PubMed]

61. Gracia-Vásquez, S.L.; Ramírez-Lara, E.; Camacho-Mora, I.A.; Cantú-Cárdenas, L.G.; Gracia-Vásquez, Y.A.; Esquivel-Ferriño, P.C.; Ramírez-Cabrera, M.A.; Gonzalez-Barranco, P. An analysis of unused and expired medications in Mexican households. Int. J. Clin. Pharm. 2015, 37, 121-126. [CrossRef]

62. Langley, C.; Marriott, J.; Mackridge, A.; Daniszewski, R. An analysis of returned medicines in primary care. Pharm World Sci. 2005, 27, 296-299. [CrossRef]

63. Mackridge, A.J.; Marriott, J.F. Returned medicines: Waste or a wasted opportunity? J. Public. Health 2007, 29, 258-262. [CrossRef]

64. Bradley, M. Waste Medication: Community Pharmacy Audit Report 2008/09; NHS Cumbria: Cumbria, UK, 2009.

65. James, T.H.; Helms, M.L.; Braund, R. Analysis of Medications Returned to Community Pharmacies. Ann. Pharmacother. 2009, 43, 1631-1635. [CrossRef]

66. Vogler, S.; Leopold, C.; Zuidberg, C.; Habl, C. Medicines discarded in household garbage: Analysis of a pharmaceutical waste sample in Vienna. J. Pharm. Policy Pr. 2014, 7, 6. [CrossRef]

67. Braund, R.; Yuen, Y.C.; Jung, J. Identification and quantification of medication returned to Otago pharmacies. NZFP 2007, 34, 258-262.

68. Alhamad, H.; Donyai, P. Intentions to "Reuse" Medication in the Future Modelled and Measured Using the Theory of Planned Behavior. Pharmacy 2020, 8, 213. [CrossRef]

69. Hui, T.K.; Donyai, P.; McCrindle, R.; Sherratt, R.S. Enabling Medicine Reuse Using a Digital Time Temperature Humidity Sensor in an Internet of Pharmaceutical Things Concept. Sensors 2020, 20, 3080. [CrossRef] [PubMed] 
70. Hui, T.K.L.; Mohammed, B.; Donyai, P.; McCrindle, R.; Sherratt, R.S. Enhancing Pharmaceutical Packaging through a Technology Ecosystem to Facilitate the Reuse of Medicines and Reduce Medicinal Waste. Pharmacy 2020, 8, 58. [CrossRef] [PubMed]

71. Chien, H.-Y.; Ko, J.-J.; Chen, Y.-C.; Weng, S.-H.; Yang, W.-C.; Chang, Y.-C.; Liu, H.-P. Study of Medication Waste in Taiwan. J. Exp. Clin. Med. 2013, 5, 69-72. [CrossRef]

Publisher's Note: MDPI stays neutral with regard to jurisdictional claims in published maps and institutional affiliations.

(C) 2020 by the authors. Licensee MDPI, Basel, Switzerland. This article is an open access article distributed under the terms and conditions of the Creative Commons Attribution (CC BY) license (http://creativecommons.org/licenses/by/4.0/). 